The Canadian Mineralogist

Vol. 43, pp. 89-104 (2005)

\title{
THE FIRST APPEARANCE OF ACTINOLITE IN THE PREHNITE-PUMPELLYITE FACIES, SIERRA NEVADA, CALIFORNIA
}

\author{
HOWARD W. DAY§ \\ Department of Geology, University of California Davis, Davis, California 95616, U.S.A. \\ RoBERT K. SPRINGER \\ Department of Geology, Brandon University, Brandon, Manitoba R7A 6A9, Canada
}

\begin{abstract}
Jurassic metavolcanic rocks in the western Sierra Nevada, California, display widespread assemblages typical of the transition from the prehnite-pumpellyite to the greenschist facies. Actinolite first appears in the assemblage quartz + albite + chlorite + epidote + pumpellyite \pm prehnite as an overgrowth on unaltered, relict grains of calcic clinopyroxene and as small acicular grains in chlorite. Chemographic and algebraic analysis of the mineral assemblages suggests that the appearance of actinolite is controlled by high-variance continuous reactions that produce actinolite + epidote at the expense of pumpellyite-( $\mathrm{Mg})+$ minor chlorite. The data also suggest that the effective bulk composition of the metamorphic assemblage becomes more magnesian with increasing progress of the reactions. We suggest that this phenomenon is best explained by the irreversible consumption of relatively magnesian, relict igneous phases or altered groundmass as the reactions proceeded. Thus, both equilibrium and non-equilibrium phenomena play an important role in explaining the systematic evolution of mineral compositions in these low-grade rocks.
\end{abstract}

Keywords: actinolite, pumpellyite, greenschist, mafic rocks, Sierra Nevada, California.

\section{SOMMAIRE}

Les roches métavolcaniques jurassiques de la zone occidentale le long de la chaîne des Sierra Nevada, en Californie, fait preuve d'assemblages répandus typiques de la transition du faciès à prehnite-pumpellyite au faciès schistes verts. L'actinolite fait son apparition dans l'assemblage quartz + albite + chlorite + épidote + pumpellyite \pm prehnite; elle se manifeste sous forme de surcroissance sur des grains reliques non altérés de clinopyroxène calcique et de petits cristaux aciculaires dans la chlorite. Une analyse chémographique et algébrique des assemblages de minéraux fait penser que l'apparition de l'actinolite est régie par des réactions continues à variance élevée qui produisent actinolite + épidote aux dépens de pumpellyite- $(\mathrm{Mg})$ et chlorite accessoire. Les données montrent aussi que la composition globale de l'assemblage métamorphique devient davantage magnésien à mesure que les réactions progressent. Ce phénomène serait dû à la participation irréversible de phases ignées reliques, relativement magnésiennes, ou bien de matrice altérée à mesure que les réactions progressaient. C'est donc dire que des phénomènes d'équilibre et de déséquilibre jouent des rôles importants dans l'évolution systématique de la composition de minéraux dans ces roches faiblement métamorphisées.

(Traduit par la Rédaction)

Mots-clés: actinolite, pumpellyite, schistes verts, roches mafiques, Sierra Nevada, Californie.

\section{INTRODUCTION}

It is well established that actinolite is common in mafic rocks belonging to the prehnite-pumpellyite facies, especially in rocks that are transitional to the greenschist facies (Beiersdorfer \& Day 1995). Analysis of the reactions by which actinolite appears in such very low-grade rocks is difficult, however, not only because of the complexity of the minerals involved, but because relict igneous minerals, textures, and barely recrystallized groundmass commonly persist through the very low-grade metamorphism. Consequently, the evolution of the observed metamorphic assemblages may involve both equilibrium and non-equilibrium processes.

In this paper, we suggest that both equilibrium and non-equilibrium phenomena play a role in explaining

$\S \quad$ E-mail address: day@geology.ucdavis.edu 
the first appearance of actinolite in some very lowgrade, metamorphosed mafic rocks in the Sierra Nevada, California. Using the techniques of singular value decomposition and linear programming to study the compositions of analyzed minerals, we propose that the first appearance of actinolite is governed by a high-variance continuous reaction having the general form: pumpellyite + chlorite + quartz $=$ actinolite + epidote + $\mathrm{H}_{2} \mathrm{O}$. However, the data also suggest that the effective bulk composition of the metamorphic assemblage becomes significantly more magnesian with advancing progress of the reaction. Although the assumption of equilibrium in the mineral assemblages successfully captures many broad features of these very-low-grade assemblages, the irreversible consumption of igneous clinopyroxene or altered groundmass may also play an important role in explaining the shift to more magnesian compositions at higher grade.

\section{BACKGROUND}

Mafic rocks at very low grades of metamorphism commonly are modeled in the simplified system $\mathrm{Na}_{2} \mathrm{O}$ $-\mathrm{CaO}-\mathrm{MgO}-\mathrm{Al}_{2} \mathrm{O}_{3}-\mathrm{SiO}_{2}-\mathrm{H}_{2} \mathrm{O}$ (NCMASH, Table 1, Fig. 1). The compositions of chlorite and calcic amphibole are represented by the end-members clinochlore

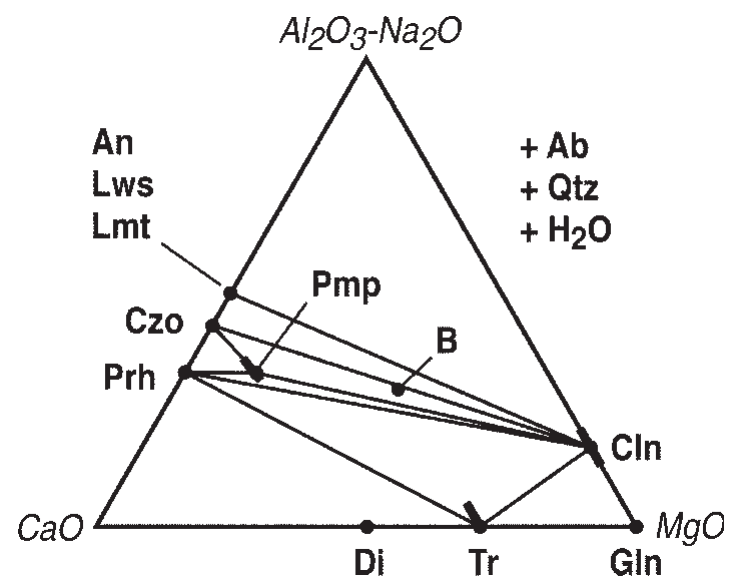

FIG. 1. Molar compositions in the model system $\mathrm{Na}_{2} \mathrm{O}-\mathrm{CaO}$ - $\mathrm{MgO}-\mathrm{Al}_{2} \mathrm{O}_{3}-\mathrm{SiO}_{2}-\mathrm{H}_{2} \mathrm{O}$ (NCMASH). Phase compositions are shown in projection from quartz, albite and $\mathrm{H}_{2} \mathrm{O}$, with transformed coordinates for plotting $\left(\mathrm{Al}_{2} \mathrm{O}_{3}-\mathrm{Na}_{2} \mathrm{O}\right)$, $\mathrm{CaO}$, and $\mathrm{MgO}$. Heavy lines show limited solid-solutions, described in text. Point " $\mathrm{B}$ " is a model composition based on the average basalt of Le Maitre (1976) that is less aluminous than the Cln-Czo join. The sodic amphibole glaucophane (Gln) is the only phase that contains essential sodium. Other sodic and sodic-calcic amphiboles such as eckermannite and richterite project to positions below the $\mathrm{CaO}-\mathrm{MgO}$ join. Symbols: An anorthite, Di diopside, Lmt laumontite, Lws lawsonite; others as in Table 1.
(Cln) and tremolite (Tr) and may vary along lines of constant $\mathrm{CaO}$ content by Tschermak's exchange (tk, Table 1, Fig. 1). Pumpellyite-( $\mathrm{Mg})$, hereafter simply pumpellyite, also may exhibit solid solution by the exchange AlMg $\mathrm{Al}_{-1} \mathrm{H}_{-1}$ (amh, Table 1, Fig. 1; Schiffman \& Day 1999). In the absence of direct determination of hydrogen concentration, a formula unit of pumpellyite having five trivalent cations and seven hydroxyl ions (Table 1) has proven to be useful for most purposes (Coombs et al. 1976, Beiersdorfer \& Day 1995). Substitution of magnesium for calcium is limited in these phases and is not illustrated.

In the model system, tremolite might be expected to appear first by discontinuous, univariant reactions such as:

$$
25 \mathrm{Pmp}+2 \mathrm{Cln}+29 \mathrm{Qtz}
$$$$
=7 \mathrm{Tr}+43 \mathrm{Czo}+67 \mathrm{H}_{2} \mathrm{O}
$$

or

$$
5 \mathrm{Prh}+\mathrm{Cln}+2 \mathrm{Qtz}=\mathrm{Tr}+4 \mathrm{Czo}+6 \mathrm{H}_{2} \mathrm{O}
$$

These reactions appear in projection as tieline changes (Fig. 1) and as the prehnite-absent and pumpellyite-absent reactions in Figure 2 (Liou et al. 1985, Frey et al. 1991, Powell et al. 1993).

Although these reactions provide a useful model for the disappearance of pumpellyite or prehnite, they do not provide a satisfactory explanation for the first appearance of amphibole because tremolite by itself is intrinsically stable throughout the diagram (Fig. 2). Tremolite occupies a chemographically exterior position with respect to the other metamorphic phases in the model system. Consequently, it can participate only in tieline changes with the other metamorphic phases; it is not possible to write a terminal reaction among the metamorphic phases by which tremolite, itself, becomes unstable with either increasing or decreasing temperature (Fig. 1; Day 1972). In order to participate in reactions such as the clinozoisite-absent reaction [(Czo), Fig. 2], tremolite must already have appeared at a lower tem-

\begin{tabular}{|c|c|c|c|c|c|c|c|c|}
\hline \multirow{2}{*}{$\begin{array}{l}\text { Name } \\
\text { Nlbite }\end{array}$} & \multirow{2}{*}{$\begin{array}{c}\text { Symbol } \\
\mathrm{Ab}\end{array}$} & \multirow{2}{*}{$\begin{array}{l}\text { Formula unit } \\
\mathrm{NaAlSi}_{3} \mathrm{O}_{8}\end{array}$} & \multicolumn{2}{|c|}{$\mathrm{Na}_{2} \mathrm{O} \mathrm{CaO}$} & \multicolumn{3}{|c|}{$\mathrm{MgOAl}_{2} \mathrm{O}_{3} \mathrm{SiO}_{2}$} & $\mathrm{II}_{2} \mathrm{O}$ \\
\hline & & & 0.5 & 0 & 0 & 0.5 & 3 & 0 \\
\hline Clinochlore & $\mathrm{Cln}$ & $\mathrm{Mg}_{5} \mathrm{AlSi}_{3} \mathrm{AlO}_{10}(\mathrm{OH})_{8}$ & 0 & 0 & 5 & 1 & 3 & 4 \\
\hline linoz & Czo & $\mathrm{Ca}_{2} \mathrm{Nl}_{3} \mathrm{Si}_{3} \mathrm{O}_{12}(\mathrm{OH})$ & 0 & 2 & 0 & 1.5 & 3 & 0.5 \\
\hline Glaucophanc & Gln & $\mathrm{Na}_{2} \mathrm{Mg}_{3} \Lambda \mathrm{I}_{2} \mathrm{Si}_{8} \mathrm{O}_{22}(\mathrm{OII})_{2}$ & 1 & 0 & 3 & 1 & 8 & 1 \\
\hline Prehnite & Prh & $\mathrm{Ca}_{2} \mathrm{Al}_{2} \mathrm{Si}_{3}(\mathrm{OH})_{2}$ & 0 & 2 & 0 & 1 & 3 & 1 \\
\hline Pumpellyite-(Mg) & g) Pmp & $\mathrm{Ca}_{4} \mathrm{Mg} \mathrm{N} / \mathrm{I}_{4} \mathrm{Si}_{6} \mathrm{O}_{20}(\mathrm{OH})$ & $7_{7} 0$ & 4 & 1 & 2.5 & 6 & 3.5 \\
\hline Quartz & Qtz & $\mathrm{SiO}_{2}$ & 0 & 0 & 0 & 0 & 1 & 0 \\
\hline Tremolite & $\mathrm{Tr}$ & $\mathrm{Ca}_{2} \mathrm{M}_{54} \mathrm{Si}_{8} \mathrm{O}_{22}(\mathrm{OH})_{2}$ & 0 & 2 & 5 & 0 & 8 & 1 \\
\hline \multirow{2}{*}{ Tschermak } & tk & $\mathrm{Al}_{2} \mathrm{Mg}_{-1} \mathrm{Si}_{-1}$ & 0 & 0 & -1 & 1 & -1 & 0 \\
\hline & anh & $\mathrm{AlMg}_{-1} \mathrm{H}_{\mathrm{il}}$ & 0 & 0 & -1 & 0.5 & 0 & -0.5 \\
\hline
\end{tabular}

TABLE 1. COMPOSITION OF MINLRALS AND EXCHANGES IN NCMASH 
perature by other mechanisms such as continuous reactions (Liou et al. 1985) or crystallization from unstable igneous materials (Coombs et al. 1976).

In natural assemblages, reactions (1) and (2) are multivariant because at least ferrous and ferric iron must be considered as additional components. Both reactants and products of reactions (1) and (2) may coexist at equilibrium, and the assemblage actinolite (Act) + epidote $(\mathrm{Ep})+$ chlorite $(\mathrm{Chl})+$ pumpellyite $(\mathrm{Pmp})$, with or without prehnite (Prh), is common in mafic rocks at very low grade (Liou et al. 1987, Beiersdorfer \& Day 1995). Such natural assemblages have been analyzed using

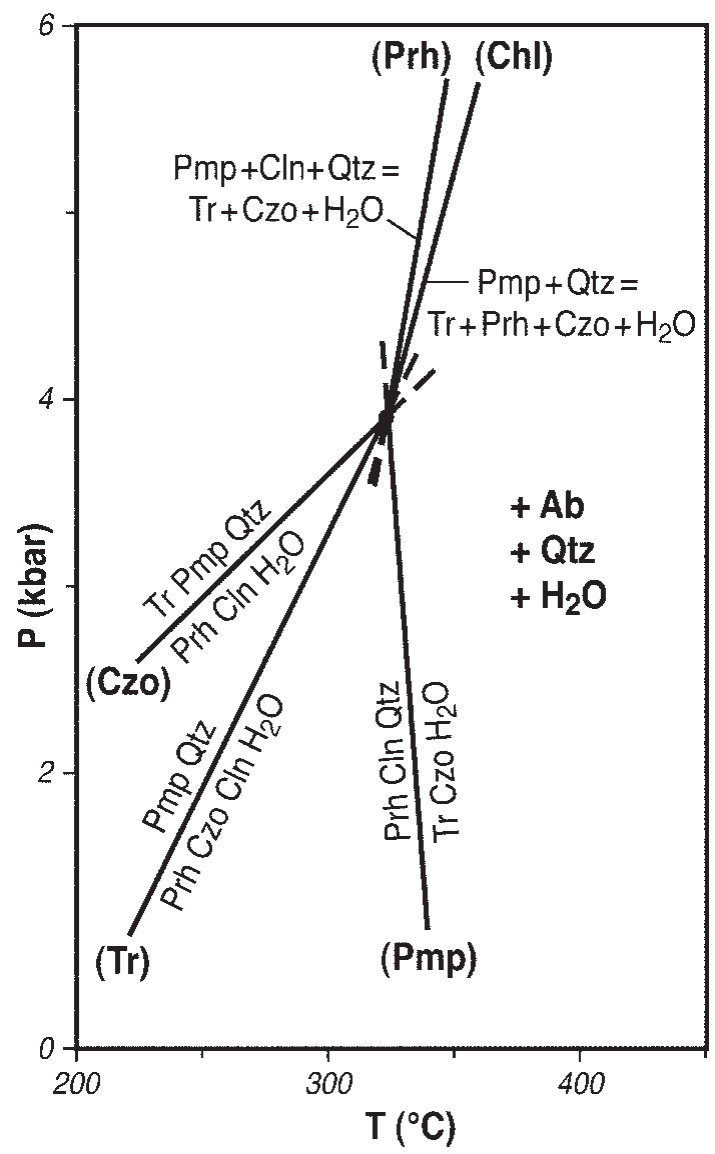

FIG. 2. Phase equilibria in NCMASH projected from excess albite, quartz and $\mathrm{H}_{2} \mathrm{O}$ (modified after Powell et al. 1993, Frey et al. 1991, Liou et al. 1987). A projection from albite is required only if the amphibole contains essential sodium. Reactions are labeled with the absent phase; in the presence of excess quartz and $\mathrm{H}_{2} \mathrm{O}$, the reactions (Qtz) and $\left(\mathrm{H}_{2} \mathrm{O}\right)$ do not occur and are not illustrated. Phases on the right-hand side of an equality represent the high-temperature side of a reaction. Model phase-compositions and symbols as in Table 1 . various projections from the ubiquitous phases quartz, albite and $\mathrm{H}_{2} \mathrm{O}$ and one or more additional phases such as epidote (Harte \& Graham 1975, Laird 1980, Beiersdorfer \& Day 1995, Bevins \& Robinson 1993), chlorite (Brown 1977, Liou et al. 1985, 1987, Patrick \& Day 1989, Bröcker \& Day 1995), or prehnite (Springer et al. 1992). The results of these analyses typically suggest that there is a broad approach to equilibrium in very low-grade assemblages such that there is a correspondence between bulk chemical composition and the observed mineral assemblages, as required by the metamorphic facies concept.

In detail, however, the effects of non-equilibrium are apparent in the chemically zoned compositions of minerals and the differences of mineral compositions among compositional domains in single thin sections. Crossing tielines are also evident in many suites of compositions, but it is difficult to know whether these represent disequilibrium, metamorphic reactions, or the failure of the projections to represent the composition space adequately (Schiffman \& Day 1999). Although it is possible to use several projections to obtain different views of the assemblage in multiple compositional dimensions, algebraic methods are required to determine both the existence and the nature of possible reaction-relationships (Greenwood 1967, Thompson et al. 1982, Fisher 1989).

We have used algebraic methods to study systematic changes in the observed compositions of metamorphic minerals in pumpellyite-bearing rocks from the Sierra Nevada. Both equilibrium and non-equilibrium processes are helpful in explaining the observations.

\section{Geological Setting}

We have studied the metamorphism of a volcanic arc in the western belt of the Sierra Nevada, one of several fault-bounded terranes of pre-batholithic rocks that lies west of the Sierra Nevada batholith (Day 1992, Schweickert et al. 1999) (Fig. 3, inset). The western belt comprises a Middle Jurassic volcanic arc and a cover of Upper Jurassic sedimentary rocks that overlies the arc conformably. The arc and its sedimentary cover were folded and faulted during the Late Jurassic Nevadan orogeny, and intruded by Late Jurassic and earliest Cretaceous granitic plutons during the period 150-140 Ma. The southern end of the western belt is intruded by plutons of the Cretaceous Sierra Nevada batholith. The Jurassic arc-cover assemblage extends approximately 300 kilometers along the western front of the Sierra Nevada, where it is overlain unconformably on the west by Upper Cretaceous and Tertiary sedimentary rocks in the Great Valley, and bounded on the north and east by prominent fault-zones known as the Big Bend - Wolf Creek fault and the Bear Mountains fault.

The volcanic rocks in the western belt are divided stratigraphically into a lower volcanic edifice-building unit and an upper volcaniclastic unit. The lower volca- 
nic unit is largely basaltic to andesitic in composition, and contains a wide range of aphyric flows, plagioclaseand clinopyroxene-phyric flows, pillowed flows, and

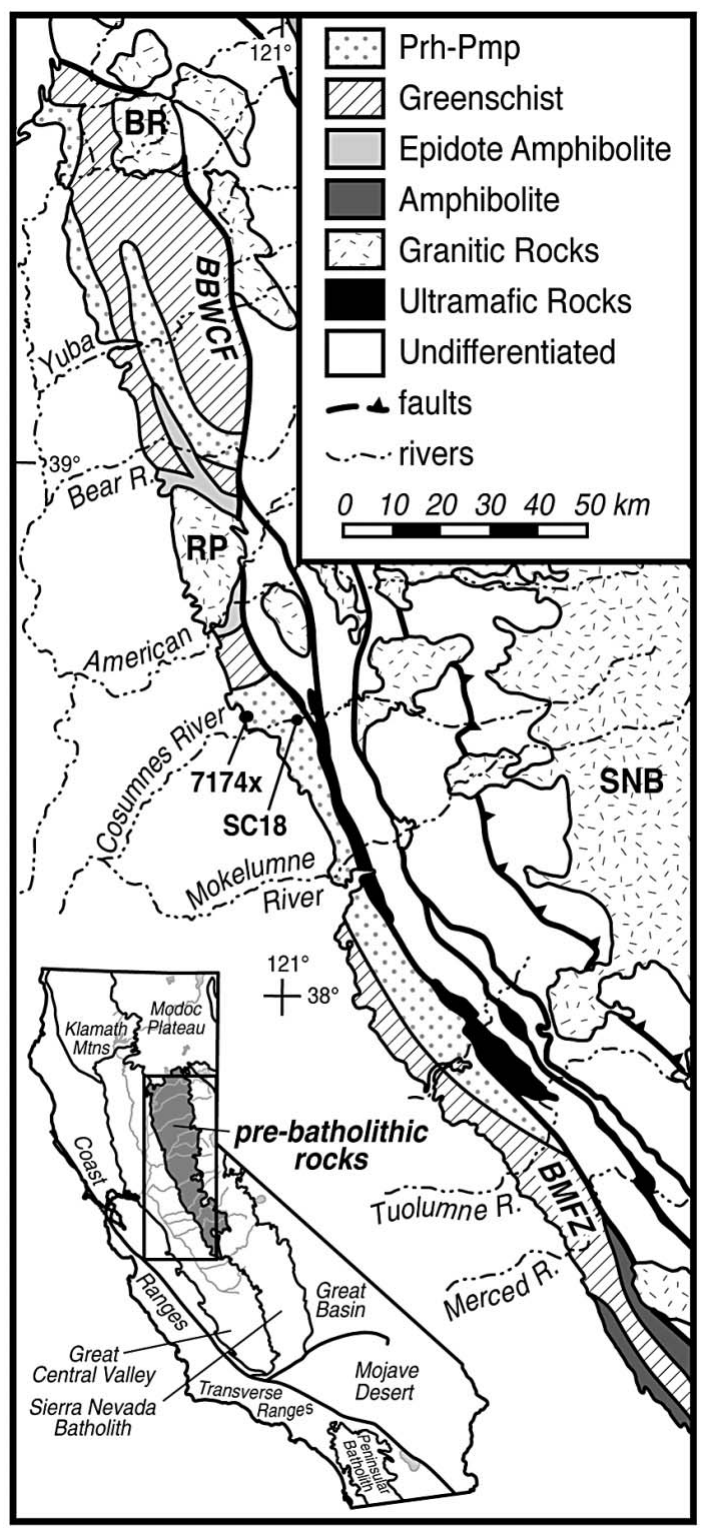

FIG. 3. Map of the metamorphic facies in the western belt, Sierra Nevada, California (after Day et al. 2003, Beiersdorfer 1992, Day \& Springer, unpubl. data). Undifferentiated rocks include Cretaceous and younger rocks in the Great Valley to the west, and Mesozoic and Paleozoic prebatholithic rocks to the east. Abbreviations: BBWCF Big Bend - Wolf Creek fault zone, BMFZ Bear Mountains fault zone, BR Bald Rock pluton, RP Rocklin - Penrhyn pluton, SNB Sierra Nevada batholith. flow breccias, as well as minor chert and volcaniclastic rocks. The upper volcanic unit consists largely of waterlaid, volcaniclastic rocks, including heterolithic volcanic breccias, conglomerates, volcaniclastic sandstones, and tuffs. Unbroken, nearly euhedral phenocrysts of augite are common in the detritus. Massive, thickly bedded units are common, but other primary structures include graded beds, rare cross-bedding and channel structures, and soft-sediment, flame structures. The contact with the overlying, siliciclastic sedimentary unit is conformable. Quartz-bearing sandstones and slates appear abruptly in the sedimentary sequence, but in some places, quartz-bearing epiclastic and volcaniclastic sedimentary rocks are interbedded near the contact between the two units.

Large granitic intrusions are rare in the western belt, but the Rocklin-Penryn (RP) and Bald Rock (BR) plutons (ca. $140 \mathrm{Ma}$, Irwin \& Wooden 2001) intrude the volcanic arc and impose greenschist- to amphibolitefacies contact aureoles (Fig. 3). On the eastern side of the belt, north of the Bear River, small intrusions related to the volcanic arc ( $c a .160 \mathrm{Ma}$, Beard \& Day 1987) are abundant, but not illustrated, and are associated with a broad zone of greenschist-facies rocks. Numerous small granitic intrusions ( $c a .140-150 \mathrm{Ma}$ ) have been described also in the southernmost part of the western belt (Tobisch et al. 1989), where the regional metamorphic grade is high. Small buried plutons may be present beneath some other areas displaying greenschistfacies assemblages (Fig. 3).

\section{Mineral Zones And Assemblages}

The western belt contains rocks that range from prehnite-pumpellyite facies to amphibolite facies (Fig. 3). In this paper, we focus exclusively on assemblages of the prehnite-pumpellyite facies that are widely distributed in the volcanic arc throughout most of the length of the western belt. These assemblages have been described in detail near the Bear and Cosumnes rivers (Fig. 3; Springer et al. 1992, Springer \& Day 2002, Beiersdorfer 1992), where two metamorphic zones within rocks of the prehnite-pumpellyite facies are too narrow to illustrate effectively in Figure 3. Zone A1 contains the assemblage $\mathrm{Qtz}+\mathrm{Ab}+\mathrm{Chl}+\mathrm{Ep}+\mathrm{Pmp} \pm$ Prh. Zone A2 contains the same assemblage with actinolite, in rocks of appropriate bulk-composition. Near the Cosumnes River, Zone A1 is confined to the westernmost part of the prehnite-pumpellyite facies near sample locality $7174 \mathrm{X}$; Zone A2 lies to the east, near the Bear Mountains fault and sample locality SC18 (Fig. 3). Zone A2 assemblages are also found near the fault farther south. However, in the south, Zone A1 occupies a central position and is separated from the greenschist-facies rocks to the west by zone A2 assemblages. Table 2 summarizes the metamorphic zones, lithologies, and assemblages of samples illustrated or discussed in this paper. Sample 79-142 comes from the 
prehnite-pumpellyite facies exposed at the Yuba River, and most other samples were collected within about ten $\mathrm{km}$ of samples SC18 and 7174X, north of the Cosumnes River (Fig. 3). Detailed sample locations are given in the Appendix (Table A1).

Zone A1 is the lowest-grade zone of metamorphism observed in the western belt. The groundmass in many rocks is incompletely recrystallized, and relict igneous augite is abundant and essentially unaltered (Fig. 4A). Plagioclase textures, including delicate quench textures, are commonly preserved, although the composition of most grains is albite. Albite, chlorite, and epidote are virtually ubiquitous in both flows and volcaniclastic rocks. Quartz commonly occurs in the groundmass of flows as anhedral grains in chlorite and as a rim around small patches of chlorite. We interpret this quartz to be an alteration product of originally glassy groundmass. Quartz also is present in amygdules and veins. In volcaniclastic rocks, quartz occurs in much the same way, but also may be present as a detrital constituent. Pumpellyite is abundant and occurs in amygdules with one or more of Chl, Qtz, Ab, Ep, or Prh (Fig. 4A). Pumpellyite is also isolated within plagioclase grains (Fig. 4B), and distributed in the groundmass of both flows and volcaniclastic rocks. Prehnite is not rare, but occurs sporadically in amygdules (Fig. 4A), veins and groundmass. Titanite (Ttn), opaque oxides and sulfides are common accessory minerals. Calcite (Cal) and white mica $(\mathrm{Wm})$ are distributed widely but sporadically.

Zone A2 is marked by the first appearance of actinolite in rocks of appropriate composition, but otherwise contains essentially the same minerals. The groundmass of the volcanic rocks tends to be coarsergrained than in Zone A1, but relict augite persists and plagioclase phenocrysts, completely transformed to albite, retain tabular, subhedral habits. In zone A2, actinolite first appears in the assemblage $\mathrm{Qtz}+\mathrm{Ab}+\mathrm{Chl}+$ Ep + Pmp \pm Prh. Typically, it occurs as small acicular

TABLE 2. MINERAL ASSEMBL AGES IN REPRESENT $\Lambda$ TIVE S $\triangle M P L E S$ OF MAFIC METAVOLCANIC ROCKS, WESTERN SIERRA NEVADA, CAIIFORNIA

\begin{tabular}{|c|c|c|c|}
\hline Sample & 7one & Rock' $^{1}$ & Assemblage ${ }^{2.3}$ \\
\hline SC $100 \mathrm{X}$ & A1 1 & $\mathrm{vb}$ & $C h l+E p+P m p+$ Prh \\
\hline 7172 & Al & $\mathrm{vcl}$ & $\mathrm{Chl}+\mathrm{Ep}+\mathrm{Pmp}$ \\
\hline $7174 X$ & Al & $\mathrm{vb}$ & $\mathrm{Chl}+\mathrm{Ep}+\mathrm{Pmp}+\mathrm{Prh}+\mathrm{Kf}$ \\
\hline $79-142$ & A1 & $\mathrm{mfl}$ & $\mathrm{ChI}+\mathrm{Ep}+\mathrm{Pmp}$ \\
\hline $\operatorname{SC5}$ & A2 & $\mathrm{vel}$ & $\mathrm{Chl}+\mathrm{Fp}+\mathrm{Pmp}+\mathrm{Prh}+\mathrm{Ac}$ \\
\hline SC18 & $\Lambda 2$ & $\mathrm{vel}$ & $\mathrm{Chl}+\mathrm{Ep}+\mathrm{Pmp}+$ Act \\
\hline $\mathrm{SC} 34$ & A2 & $\mathrm{vcl}$ & $\mathrm{Chl}+\mathrm{Ep}+\mathrm{Pmp}+\Lambda \mathrm{ct}$ \\
\hline SC52 & A2 & $\mathrm{vcl}$ & $\mathrm{Chl}+\mathrm{Ep}+\mathrm{Pmp}+\mathrm{Act}$ \\
\hline B62 & $\mathrm{A} 2$ & $\mathrm{vcl}$ & $\mathrm{Ch} l+\mathrm{Pmp}+\mathrm{Act}+\mathrm{K} \mathrm{Cs}_{\mathrm{s}}$ \\
\hline
\end{tabular}

'Abbreviations: $\mathrm{m} n$, mafic flow rock; $\mathrm{vb}$, homolithic volcanic flow breccia; $\mathrm{vcl}$, volcaniclastic rock.

Mineral symbols: Ab albite, Act actinolite, Cal calcite, Chl chlorite, Cpx clinopyroxene, Fp epidote, Kfs K-feldspar, Pmp pumpellyite, Prh prehnite, Qtz quartz, Stp stilpnomelane, Ttn titanite, Wm white mica.

${ }^{3}$ In addition to: $\mathrm{Ab}+\mathrm{Qtz}+\mathrm{Ttn} \pm \mathrm{Wm} \pm \mathrm{Fe}-\mathrm{Ti}$ oxides $\pm \mathrm{Cal}$ and relict $\mathrm{Cpx}$

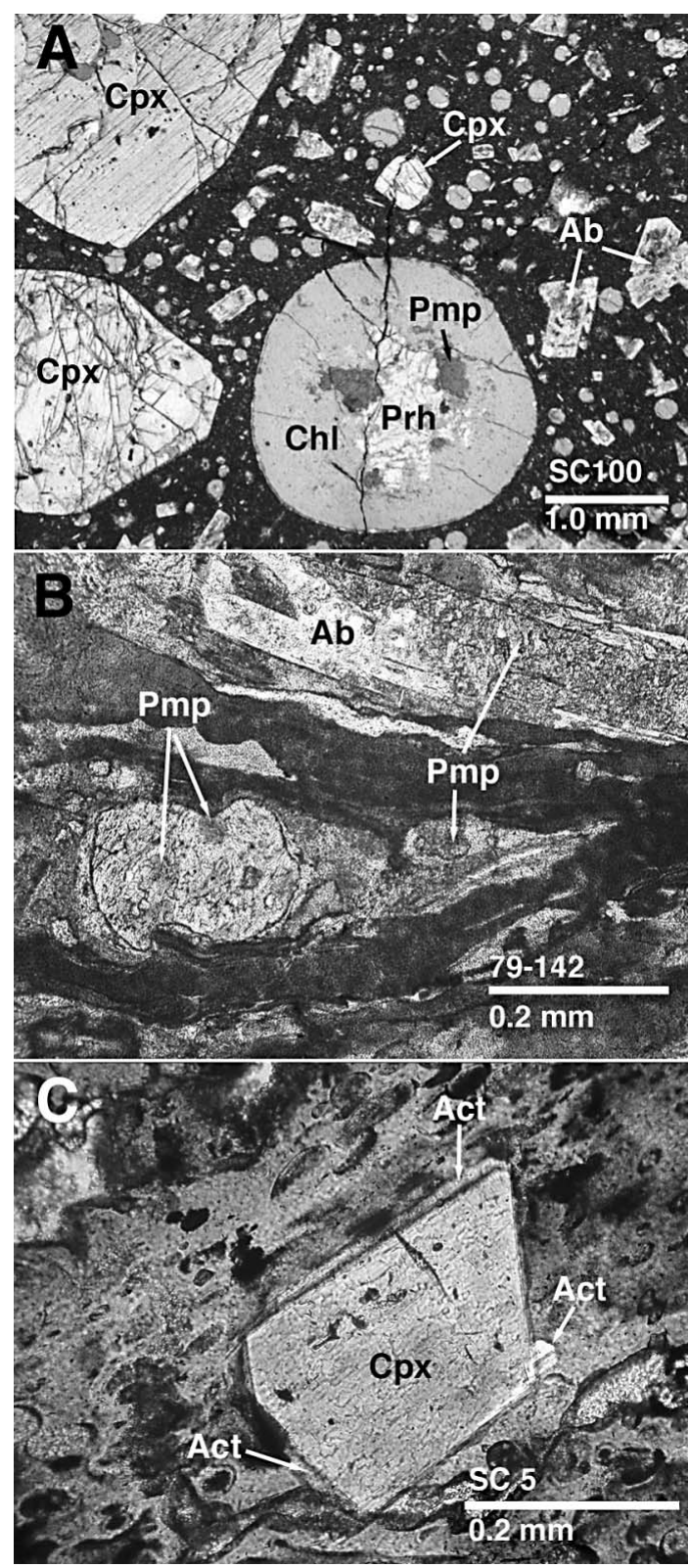

FIG. 4. Minerals and textures in Zone A. (A) Relict minerals and textures in a mafic flow breccia (sample SC100X, Zone A1). Clinopyroxene occurs as slightly altered euhedral phenocrysts. Euhedral or subhedral phenocrysts of plagioclase are entirely albite. Undeformed amygdules contain Pmp + Prh + Chl, but are commonly filled with mixtures of Chl, Qtz and Ep. (B) Pumpellyite in plagioclase. Sample is a hyaloclastite from a pillowed flow [79-142, Zone A1)]. Pumpellyite also occurs in amygdules with Chl + Qtz \pm Ep and in the groundmass. (C) Incipient overgrowths of actinolite on euhedral clinopyroxene. The mineralogy of the groundmass cannot be resolved. Sample from the upper, volcaniclastic unit (SC5, Zone A2). 
grains in chlorite-rich regions (Fig. 3f in Springer \& Day 2002) or as epitactic overgrowths on augite (Fig. 4C).

Pumpellyite is very common and abundant in zone A1 (typically $5-10 \%$ in mafic rocks), where actinolite is absent. In zone A2, the abundance of pumpellyite progressively decreases to much less than $1 \%$ near the greenschist-facies boundary, where it disappears. Actinolite increases from a trace to $5-10 \%$ near the greenschist-facies boundary. In most rocks throughout zones A1 and A2, augite phenocrysts remain essentially unaltered and display sharp contacts with the groundmass. In some rocks, augite phenocrysts exhibit alteration to chlorite \pm epidote along cleavage planes or at grain margins. In the greenschist facies, clinopyroxene is progressively replaced by actinolite and disappears (Fagan \& Day 1997).

\section{Mineral Reactions}

In rocks that are well described by the system $\mathrm{NCMASH}+\mathrm{FeO}+\mathrm{Fe}_{2} \mathrm{O}_{3}$, two mineral projections might be used to analyze equilibria in the assemblage $\mathrm{Qtz}+\mathrm{Ab}+\mathrm{Ep}+\mathrm{Chl}+\mathrm{Pmp}+$ Act \pm Prh (Fig. 5). The "epidote" projection uses the phases quartz, albite, $\mathrm{H}_{2} \mathrm{O}$, and epidote as projection points and displays assemblages on an image plane that includes $\mathrm{Al}_{2} \mathrm{O}_{3}, \mathrm{FeO}$ and MgO (Harte \& Graham 1975, Beiersdorfer \& Day 1995) (Fig. 5A). In order to accomplish the projection, the components $\mathrm{Al}_{2} \mathrm{O}_{3}$ and $\mathrm{Fe}_{2} \mathrm{O}_{3}$ must be combined, so that the effects of solid solution on mineral compositions and equilibria are hidden. The "chlorite" projection illustrated here (Fig. 5B) uses the phases quartz, albite, $\mathrm{H}_{2} \mathrm{O}$ and clinochlore as projection points and displays min-
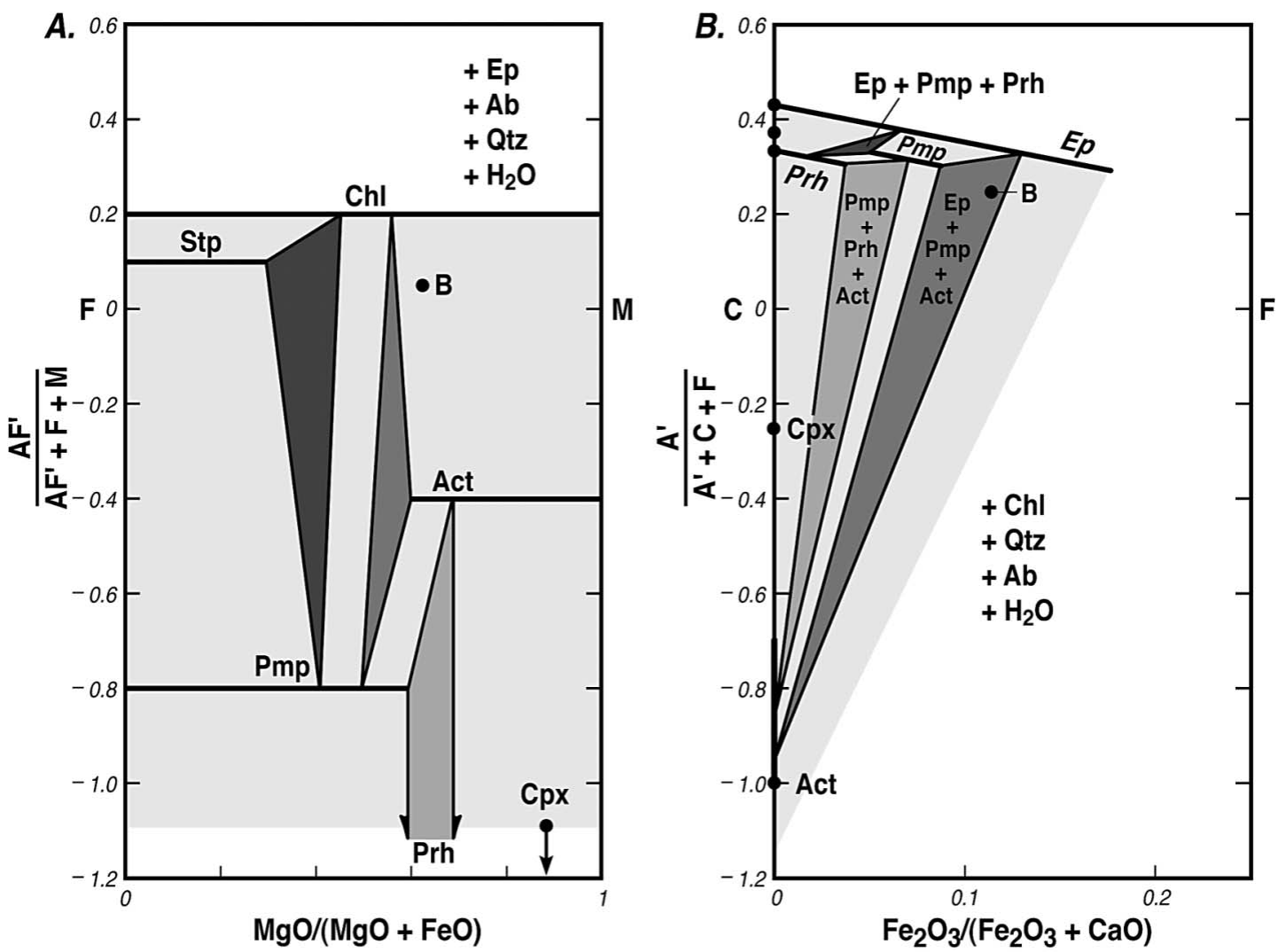

FIG. 5. Mineral projections in the system $\mathrm{NCMASH}+\mathrm{FeO}+\mathrm{Fe}_{2} \mathrm{O}_{3}$. Mineral compositions and assemblages are based on a representative model topology for prehnite-pumpellyite-facies rocks (Springer et al. 1992, Bevins \& Robinson 1993, Beiersdorfer \& Day 1995). Point "B" is a model composition based on the average basalt of Le Maitre (1976). Point "Cpx" is a typical composition of relict igneous clinopyroxene in these rocks (Xenophontos 1984). (A) Epidote projection. Plotting coordinates: $\mathrm{AF}^{\prime}=\left(\mathrm{Al}_{2} \mathrm{O}_{3}+\mathrm{Fe}_{2} \mathrm{O}_{3}\right)-\mathrm{Na}_{2} \mathrm{O}-0.75 \mathrm{CaO}, \mathrm{F}=\mathrm{FeO}, \mathrm{M}=\mathrm{MgO}$. (B) Chlorite projection. Plotting coordinates: $\mathrm{A}^{\prime}=\mathrm{Al}_{2} \mathrm{O}_{3}-0.2(\mathrm{MgO}+\mathrm{FeO})-\mathrm{Na}_{2} \mathrm{O}, \mathrm{C}=\mathrm{CaO}, \mathrm{F}=\mathrm{Fe}_{2} \mathrm{O}_{3}$ 
eral compositions on the image plane that includes $\mathrm{Al}_{2} \mathrm{O}_{3}, \mathrm{CaO}$ and $\mathrm{MgO}$. Various other versions of "chlorite" projections have been used in the literature (Brown 1977, Liou et al. 1985, 1987, Patrick \& Day 1989, Bröcker \& Day, 1995), but all versions require that $\mathrm{MgO}$ and $\mathrm{FeO}$ be combined as components, and all fail to preserve the $\mathrm{Fe}^{3+} /\left(\mathrm{Fe}^{3+}+\mathrm{Al}\right)$ value of the minerals being projected (Schiffman \& Day 1999). Both projections yield crossing tielines if prehnite is present in the common assemblage, $\mathrm{Qtz}+\mathrm{Ab}+\mathrm{Ep}+\mathrm{Chl}+\mathrm{Pmp}+\mathrm{Act}$, because the dimensions of the composition space have been reduced by combining components.

On the basis of Figure 5, it is clear that the presence or absence of actinolite in rocks containing pumpellyite or prehnite can be controlled in part by chemical composition; such control might explain the differences between Zone $\mathrm{A} 1$ and $\mathrm{A} 2$. For example, low $\mathrm{MgO}$ contents (Fig. 5A) or high $\mathrm{Al}_{2} \mathrm{O}_{3}$ contents (Fig. 5B) might explain the absence of actinolite in zone A1.
Our observations suggest that there is a reaction relationship between the common assemblages in Zones A1 and A2 (Figs. 6A, B). Tielines linking the phases $\mathrm{Pmp}+\mathrm{Chl}+\mathrm{Ep}$ in rocks from Zone A1 span the darkly shaded fields illustrated in Figure 6. These assemblages appear as Pmp $+\mathrm{Chl}$ tielines in the epidote projection (Fig. 6A) and as Pmp + Ep tielines in the chlorite projection (Fig. 6B). Tielines linking the phases Act + Pmp $+\mathrm{Chl}+\mathrm{Ep}$ in Zone A2 assemblages appear as the threephase triangles in Figure 6 and clearly cross the tielines representing the actinolite-free assemblages from Zone A1. The fact that the three-phase triangles representing the Zone A2 assemblages overlap one another may reflect failure of the rocks to equilibrate fully, deficiencies in the projections, discussed above, or sensitivity of equilibrium compositions to minor differences in the physical conditions of metamorphism.

Although both views of composition space suggest that the assemblages of zones A1 and A2 have a reac-
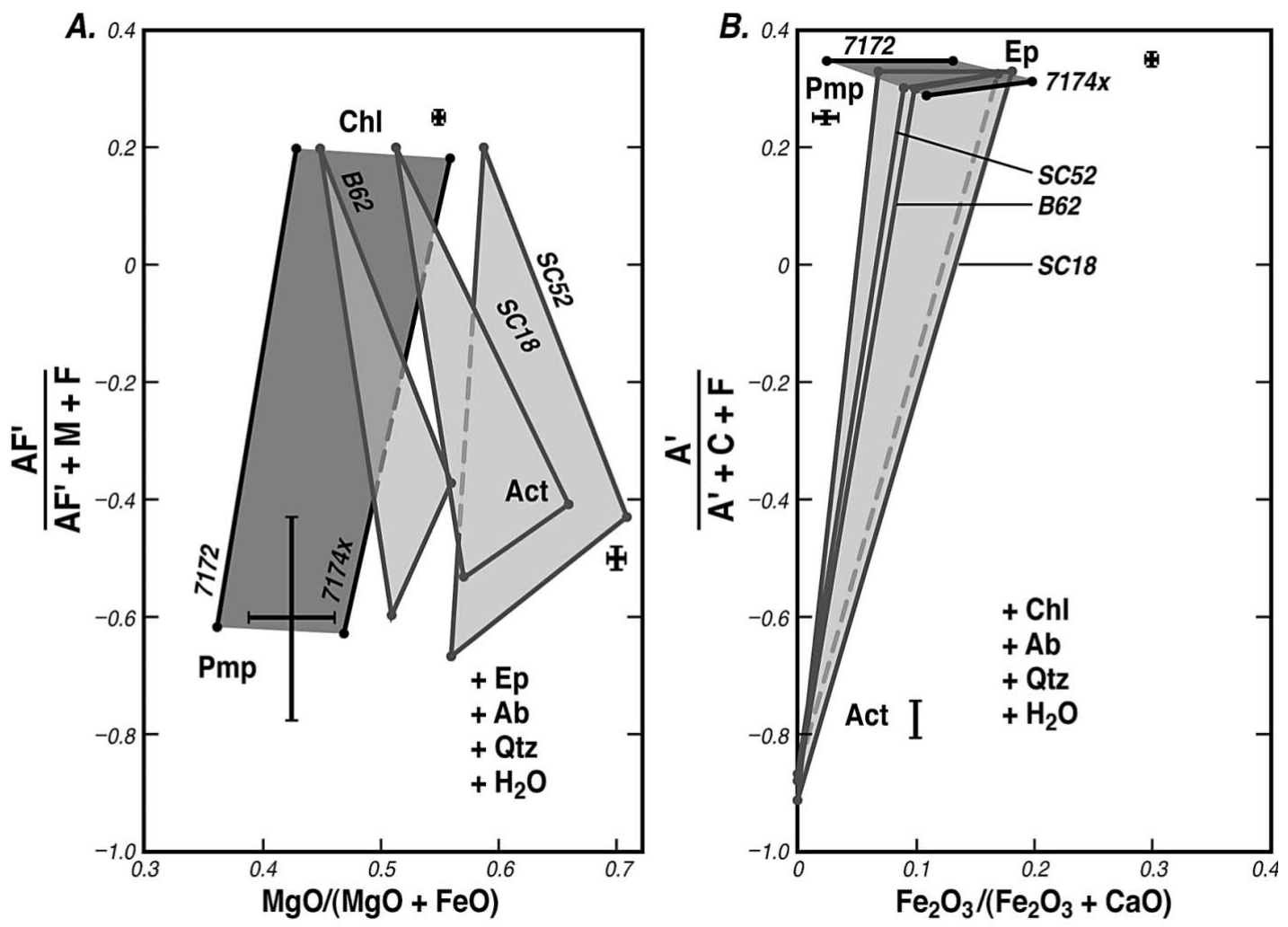

FIG. 6. Projections for selected samples from the Sierra Nevada. (A) Epidote projection; (B) Chlorite projection. Typical error bars $( \pm 1 \sigma)$ are illustrated for each phase. They include not only analytical uncertainty but also the variation of mineral compositions between domains in a polished section. The field of Pmp + Chl tielines for samples from zone A1 is indicated by the dark shading. Selected Pmp $+\mathrm{Chl}+$ Act assemblages are shown as lightly shaded triangles. Plotting coordinates as in Figure 5 . 
tion relationship to one another, this conclusion is not robust because the projections themselves are not rigorous treatments of the natural assemblages. Not all components are included in the projections, components are combined in order to reduce the dimensions of the composition space, and projections are made from constant compositions of chlorite and epidote that, in fact, have variable compositions. Furthermore, the nature of the reaction by which actinolite appears in these assemblages is not obvious from these views of composition space.

In order to determine whether or not reaction relationships exist among the observed assemblages, and the nature of possible reaction-relationships, we have used singular value decomposition of matrices of mineral compositions (Fisher 1989) to study the possible massbalances between the assemblages in zones A1 and A2. We then illustrate the possible mass-balances in a reaction space based on the natural assemblages (Fisher 1990).

\section{Singular value decomposition}

Fisher (1989) described the application of singular value decomposition (SVD) to matrices of mineral compositions. Briefly, the results of SVD analysis yield two important pieces of information that are useful for the interpretation of mineral equilibria: (1) the rank of a model composition matrix that fits the analyzed minerals within analytical uncertainty, which is equivalent to the number of independent chemical components necessary to describe the assemblage; (2) the number and identity of independent mass-balances among the model minerals, which can be used to construct a reaction space (Thompson 1982, Fisher 1990) that includes all possible mass-balance relationships among the analyzed minerals.

As outlined by Fisher (1989), any $n \times m$ matrix M, composed of $n$ components and $m$ phases, can be decomposed by SVD into the product of three matrices, $\mathbf{U}, \mathbf{W}$, and $\mathbf{V}$, such that:

$$
\begin{aligned}
& \mathbf{M}=\mathbf{U} \cdot \mathbf{W} \bullet \mathbf{V}^{\mathrm{t}} \\
& {[n \times m]=[n \times n][n \times m][m \times m]}
\end{aligned}
$$

where $\mathbf{V}^{t}$ is the transpose of $\mathbf{V}$, and the dimensions of the matrices are indicated in brackets. The number of independent components in the phase assemblage, or rank of $\mathbf{M}$, is given by the number of non-zero elements in the diagonal of matrix $\mathbf{W}$. The columns of $\mathbf{U}$ that correspond to the non-zero elements in the diagonal of W may be used as a new set of basis vectors (or independent components) for composition space, and the columns of $\mathbf{V}$ corresponding to the zero diagonal elements of $\mathbf{W}$ provide new basis-vectors for a reaction space among those minerals. Fisher (1989) gave several examples. We used MATLAB software (Mathworks,
Inc., Natick, Massachusetts 01760) to perform the singular value decomposition.

The SVD analysis of compositions of natural minerals yields a nominal rank (or number of components) for the mineral matrix. As noted by Fisher (1989), the matrix may be within analytical uncertainty of a model matrix of lower rank. If the last singular value in the diagonal of $\mathbf{W}$ is much smaller than the others, and near zero, that element is set equal to zero and a new model composition matrix is created:

\section{$\mathbf{M M}=\mathbf{U} \cdot \mathbf{W M} \cdot \mathbf{V}^{\mathrm{t}}$}

where $\mathbf{W M}$ is the modified matrix $\mathbf{W}$. The new model matrix, MM, can be compared with the original matrix, $\mathbf{M}$, and the differences compared with analytical uncertainties (Fisher 1989).

Whether or not a trial model should be rejected requires detailed information about analytical uncertainties. Our analyses of samples 7174X and SC18 (Fig. 2) are presented as the mean and standard deviation of results of several analyses from the same thin section (Appendix, Table A2). If more than a few compositions are available, the uncertainties may be large, and include not only analytical error, but also the natural variation of compositions within the sample. In view of the difficulty of analyzing fine-grained, low-grade rocks, the larger uncertainties are probably a better estimate of our confidence in the compositions than uncertainties based on counting errors of single electron-microprobe analyses. We rejected trial models of lower rank using several criteria. Some models were rejected because they require significant negative contents of one or more elements in one or more minerals. Other models were rejected because they require that a phase contain a significant amount of an element not present above its lower limit of detection. Finally, some models were rejected because residuals of one or more elements in a model composition exceed the uncertainty in the analy$\operatorname{sis}(2 \sigma)$.

In order to simplify the modeling, we projected all mineral compositions from $\mathrm{SiO}_{2}, \mathrm{H}_{2} \mathrm{O}$ and $\mathrm{NaAlSi}_{3} \mathrm{O}_{8}$, and eliminated these components as well as the phases quartz, albite and $\mathrm{H}_{2} \mathrm{O}$ from the models. The molar $\mathrm{Al}_{2} \mathrm{O}_{3}$ content of sodium-bearing phases must be recalculated as $\left(\mathrm{Al}_{2} \mathrm{O}_{3}-\mathrm{Na}_{2} \mathrm{O}\right)$, but other than albite, only actinolite contains detectable sodium. Because we hoped to obtain results that could be generalized to all common assemblages, as a first step we neglected the possible roles of calcite, white mica, and prehnite. The presence of these phases is minor and sporadic, and the stability of pumpellyite or prehnite requires that the $\mathrm{CO}_{2}$ content of the natural fluid be low.

\section{Using SVD to define a reaction space}

The composition matrices of samples $7174 \mathrm{X}$ and SC18 (Table 3) were combined in order to test for reac- 
tion relationships that would indicate the formation of the two assemblages under different physical conditions. The analytical results are given in units of moles of oxide per formula unit and are based on the analytical data and structural formulas summarized in the Appendix. Iron in chlorite was assumed to be divalent. The calculated content of ferric iron in most actinolite samples was found to be indistinguishable from zero, so all iron was assumed to be divalent. Iron in epidote was assumed to be trivalent, and ferrous and ferric iron were calculated for pumpellyite by assuming 24.5 atoms of oxygen and 16 cations (Coombs et al. 1976).

Singular value decomposition shows that the combined matrix has a nominal rank of 6 , but a rank-5 model has very low residuals and cannot be distinguished from the analytical data within analytical uncertainties

\begin{tabular}{|c|c|c|c|c|c|c|c|}
\hline Observed & Chl1 & Fp1 & Pmpl & Act2 & $\mathrm{Ch} 12$ & Ep2 & Pmp2 \\
\hline $\mathrm{Al}_{2} \mathrm{O}_{3}$ & 1.0834 & 1.0840 & 2.0323 & 0.0409 & 1.2052 & 1.1642 & 2.2453 \\
\hline $\mathrm{Fe}_{2} \mathrm{O}_{3}$ & 0.0000 & 0.4923 & 0.4616 & 0.0000 & 0.0000 & 0.4221 & 0.3077 \\
\hline $\mathrm{FeO}$ & 2.0700 & 0.0000 & 0.5867 & 1.6380 & 2.2866 & 0.0000 & 0.4458 \\
\hline $\mathrm{MnO}$ & 0.0400 & 0.0126 & 0.0147 & 0.0385 & 0.0407 & 0.0160 & 0.0366 \\
\hline MgO & 2.7673 & 0.0000 & 0.5115 & 3.2407 & 2.4554 & 0.0000 & 0.5839 \\
\hline $\mathrm{CaO}$ & 0.0144 & 1.9158 & 3.8933 & 1.9586 & 0.0176 & 1.9640 & 3.8808 \\
\hline R5 model & Chll & Ep1 & Pmpl & Act2 & $\mathrm{Ch} 12$ & Ep2 & Pmp2 \\
\hline $\mathrm{Al}_{2} \mathrm{O}_{3}$ & 1.0833 & 1.0840 & 2.0322 & 0.0409 & 1.2053 & 1.1643 & 2.2454 \\
\hline $\mathrm{Fe}_{2} \mathrm{O}_{3}$ & 0.0000 & 0.4923 & 0.4616 & 0.0000 & 0.0000 & 0.4221 & 0.3077 \\
\hline $\mathrm{FeO}$ & 2.0702 & 0.0000 & 0.5869 & 1.6380 & 2.2865 & -0.0001 & 0.4457 \\
\hline $\mathrm{MnO}$ & 0.0461 & 0.0111 & 0.0215 & 0.0371 & 0.0352 & 0.0131 & 0.0327 \\
\hline $\mathrm{MgO}$ & 2.7671 & 0.0000 & 0.5113 & 3.2407 & 2.4555 & 0.0001 & 0.5840 \\
\hline $\mathrm{CaO}$ & 0.0144 & 1.9158 & 3.8933 & 1.9586 & 0.0176 & 1.9640 & 3.8808 \\
\hline Residuals & Chl1 & Epl & Pmp1 & Act2 & Chl2 & Еp2 & Pmp2 \\
\hline $\mathrm{Al}_{2} \mathrm{O}_{7}$ & -0.0001 & 0.0000 & -0.0001 & 0.0000 & 0.0001 & 0.0001 & $0.000 \mathrm{I}$ \\
\hline $\mathrm{Fe}_{2} \mathrm{O}_{3}$ & 0.0000 & 0.0000 & 0.0000 & 0.0000 & 0.0000 & 0.0000 & 0.0000 \\
\hline $\mathrm{FeO}$ & 0.0002 & 0.0000 & 0.0002 & 0.0000 & -0.0001 & -0.0001 & -0.0001 \\
\hline $\mathrm{MnO}$ & 0.0061 & -0.0015 & 0.0068 & -0.0014 & -0.0055 & -0.0029 & -0.0039 \\
\hline $\mathrm{MgO}$ & -0.0002 & 0.0000 & -0.0002 & 0.0000 & 0.0001 & 0.0001 & 0.0001 \\
\hline $\mathrm{CaO}$ & 0.0000 & 0.0000 & 0.0000 & 0.0000 & 0.0000 & 0.0000 & 0.0000 \\
\hline \multirow[t]{6}{*}{ U } & 0.4313 & 0.1417 & 0.8076 & -0.0320 & 0.3745 & -0.0218 & \\
\hline & 0.0777 & 0.0890 & 0.0749 & -0.9212 & -0.3630 & 0.0065 & \\
\hline & 0.3090 & -0.4851 & 0.2656 & 0.2844 & -0.7192 & 0.0246 & \\
\hline & 0.0091 & -0.0063 & 0.0041 & -0.0084 & 0.0405 & 0.9991 & \\
\hline & 0.4278 & -0.6859 & -0.3205 & -0.2286 & 0.4368 & -0.0265 & \\
\hline & 0.7276 & 0.5159 & -0.4111 & 0.1311 & -0.1352 & 0.0049 & \\
\hline \multirow[t]{6}{*}{ w } & 7.9993 & 0.0000 & 0.0000 & 0.0000 & 0.0000 & 0.0000 & 0.0000 \\
\hline & 0.0000 & 5.2087 & 0.0000 & 0.0000 & 0.0000 & 0.0000 & 0.0000 \\
\hline & 0.0000 & 0.0000 & 1.6943 & 0.0000 & 0.0000 & 0.0000 & 0.0000 \\
\hline & 0.0000 & 0.0000 & 0.0000 & 0.3466 & 0.0000 & 0.0000 & 0.0000 \\
\hline & 0.0000 & 0.0000 & 0.0000 & 0.0000 & 0.2621 & 0.0000 & 0.0000 \\
\hline & 0.0000 & 0.0000 & 0.0000 & 0.0000 & 0.0000 & 0.0000 & 0.0000 \\
\hline \multirow[t]{7}{*}{ v } & 0.2877 & -0.5264 & 0.3139 & -0.2223 & 0.4783 & -0.4866 & 0.1632 \\
\hline & 0.2375 & 0.2276 & 0.0736 & -0.6843 & -0.1192 & 0.3211 & 0.5485 \\
\hline & 0.5182 & 0.3268 & 0.0397 & 0.2017 & -0.4988 & -0.5670 & 0.1099 \\
\hline & 0.4170 & -0.3842 & -0.8119 & -0.0571 & -0.0399 & 0.1070 & -0.0545 \\
\hline & 0.2863 & -0.5018 & 0.4642 & 0.1511 & -0.4634 & 0.4379 & -0.1465 \\
\hline & 0.2455 & 0.2334 & 0.0971 & -0.4869 & 0.0683 & -0.0220 & -0.7960 \\
\hline & 0.5255 & 0.3323 & 0.1017 & 0.4225 & 0.5359 & 0.3673 & 0.0494 \\
\hline
\end{tabular}

Assemblage $1=7174 \mathrm{X}$. Assemblage $2=\mathrm{SC} 18 . \mathrm{Al}_{2} \mathrm{O}_{3}$ in actinolite is reported as $\left(\mathrm{Al}_{2} \mathrm{O}_{3}-\mathrm{Na}_{2} \mathrm{O}\right)$, as discussed in the text.
(Table 3). Furthermore, all concentrations that were originally nil remain so in the model, and the only negative content is insignificant. A rank- 4 model for the mineral compositions was rejected because residuals of total iron in both chlorite and pumpellyite exceeded $2 \sigma$. In addition, the model requires $\mathrm{MgO}$ contents in epidote above the lower limit of detection, but none was detected in the analysis.

Singular value decomposition of the model matrix to form $\mathbf{U}, \mathbf{W}$, and $\mathbf{V}$ (Table 3) confirms that the model has a rank of 5 . The first five columns of $\mathbf{U}$, corresponding to the non-zero elements of the diagonal in $\mathbf{W}$, could serve as a basis for composition space, and the last two columns of $\mathbf{V}$, corresponding to the zero diagonal elements of $\mathbf{W}$, form the basis vectors for a reaction space (Fisher 1989).

The last two columns of $\mathbf{V}$ are recast as matrix $\mathbf{A}$ (Table 4), and are illustrated in Figure 7 as the basis vectors of a reaction space (Fisher 1990). The elements of $\mathbf{A}$ represent coefficients of the constituent minerals in two mass-balances having the forms:

$$
\begin{aligned}
& (\mathrm{MB} 1) \mathrm{Act}_{2}+\mathrm{Chl}_{2}+\mathrm{Pmp}_{2} \\
& +\mathrm{Ep}_{1}-\mathrm{Ch}_{1}-\mathrm{Pmp}_{1}-\mathrm{Ep}_{2}=0
\end{aligned}
$$

\begin{tabular}{|c|c|c|c|c|}
\hline \multirow[b]{2}{*}{ ORIGINAL } & \multicolumn{2}{|c|}{$\mathbf{A}$} & \multirow[t]{2}{*}{$\mathbf{X}$} & \multirow[t]{2}{*}{ B } \\
\hline & MB1 & MB2 & & \\
\hline Chll & -0.4866 & 0.1632 & $\mathrm{x} 1$ & $<0$ \\
\hline Epl & 0.3211 & 0.5485 & $x 2$ & $<0$ \\
\hline Pmp1 & -0.5670 & 0.1099 & & $<0$ \\
\hline Act2 & 0.1070 & -0.0545 & & $>0$ \\
\hline $\mathrm{Chl} 2$ & 0.4379 & -0.1465 & & $>0$ \\
\hline Ep2 & -0.0220 & -0.7960 & & $>0$ \\
\hline Pmp2 & 0.3673 & 0.0494 & & $>0$ \\
\hline MODIFIED & & & $\mathbf{x}$ & B \\
\hline Chl1 & -0.4866 & 0.1632 & $\mathrm{x} 1$ & $<0$ \\
\hline Ep1 & 0.3211 & 0.5485 & $x 2$ & $<0$ \\
\hline Pmpl & -0.5670 & 0.1099 & & $<0$ \\
\hline Act2 & -0.1070 & 0.0545 & & $=-1$ \\
\hline $\mathrm{Chl} 2$ & -0.4379 & 0.1465 & & $<0$ \\
\hline Ep2 & 0.0220 & 0.7960 & & $<0$ \\
\hline Pmp2 & -0.3673 & -0.0494 & & $<0$ \\
\hline
\end{tabular}

TABLE 4. FORMULATING THE LINEAR PROGRAMMING PROBLEM

\begin{tabular}{lrc} 
& \multicolumn{2}{c}{ FEASIBLE SOLUTIONS FOR X } \\
Objective & Min x1 & Max x1 \\
Criteria & Min x2 & Max x2 \\
x 1 & 1.9497 & 7.1994 \\
x2 & -14.5116 & -4.2145
\end{tabular}

$\begin{array}{lcc} & \text { PHASE COEFFICIENTS IN FE } A \text { SIBLE M } \Lambda \text { SS-B } A \text { L } \Lambda \text { NCES } \\ \text { Chl1 } & (\text { Pmp2) } & \text { (Ep1) } \\ \text { Ep1 } & -3.3169 & -4.1910 \\ \text { Pmp1 } & -7.3335 & 0.0000 \\ \text { Ac12 } & -2.7007 & -4.5457 \\ \text { Ch12 } & 1.0000 & 1.0000 \\ \text { Ep2 } & 2.9802 & 3.7700 \\ \text { Pmp2 } & 11.5078 & 3.1963 \\ \text { Pmp } & 0.0000 & 2.4366\end{array}$


and

$$
\begin{aligned}
& (\mathrm{MB} 2) \mathrm{Chl}_{1}+\mathrm{Ep}_{1}+\mathrm{Pmp}_{1} \\
& +\mathrm{Pmp}_{2}-\mathrm{Act}_{2}-\mathrm{Ch}_{2}-\mathrm{Ep}_{2}=0
\end{aligned}
$$

where the compositions of the minerals are the model compositions in the rank-5 matrix (Table 3). Negative coefficients may be considered to belong to reactants and positive coefficients, to products of a reaction. In Figure 7 , reactants on the left of the equality may be written on the counterclockwise side of a vector, and products on the right of the equality, on the clockwise side (Fisher 1990). Reaction progress is positive in the direction of increasing (positive) products. Any of the infinite number of linear combinations of these basis vectors represents a possible mass-balance among the phases.

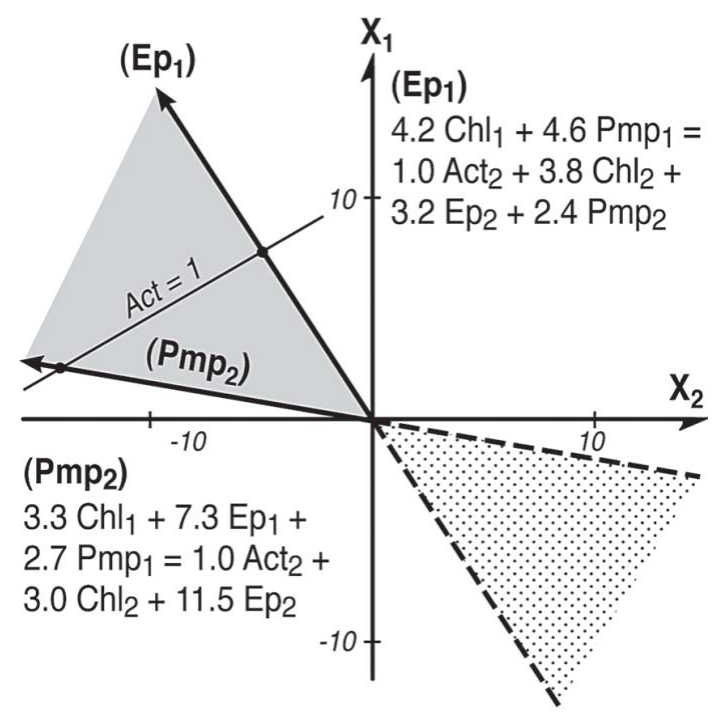

FIG. 7. Reaction space for samples 7174X and SC18. Coefficients of the phases in the mass-balances for each basis vector, $\mathrm{MB}_{1}$ and $\mathrm{MB}_{2}$, are listed in Table 4 . A scale of ten units of progress is indicated on each basis vector. The vectors (Ep1) and (Pmp2) represent the reactions that limit the region of all reactions satisfying the constraints in Table 4 (see text for explanation). Coefficients of the phases in (Ep1) and (Pmp2) have been rounded (Table 4). The feasible solutions for $\mathrm{X}_{1}$ and $\mathrm{X}_{2}$ illustrated as dots are the extreme limits of solutions for unit actinolite and are the values listed in Table 4. By convention, the assemblage on the left of the equality represents the reactants on the counterclockwise side of a vector, whereas assemblages on the right are products, which are written on the clockwise side of each vector (Fisher 1990).
Exploring the reaction space using linear programming

The basis vectors themselves cannot represent possible reactions between assemblages in zones A1 and A2, because phases from each assemblage occur as both products $(+)$ and reactants $(-)$. If a reaction relationship exists between assemblages 1 and 2, all minerals of one assemblage must lie on the opposite side of the reaction from the minerals of the other assemblage. Fisher (1989, 1990) called such assemblages "incompatibility assemblages" because they are incompatible with the hypothesis that they formed at the same grade of metamorphism. Is there is any linear combination of the basis vectors that satisfies the condition that all coefficients of phases in assemblage- 1 have signs opposite to those in assemblage-2?

This is a simple linear programming problem (Hadley 1962, Hillier \& Lieberman 1974) that is easily answered in the MATLAB environment. The coefficients of $m$ phases in a possible mass-balance are given by the elements of $\mathbf{B}$, which are linear combinations of the coefficients in the columns of $\mathbf{A}$ :

$$
\begin{aligned}
& \mathbf{A} \cdot \mathbf{X}=\mathbf{B} \\
& {[m \times 2][2 \times 1]=[m \times 1] .} \\
& \mathrm{a}_{11} * \mathrm{x}_{1}+\mathrm{a}_{12} * \mathrm{x}_{2}=\mathrm{b}_{1} \\
& \mathrm{a}_{21} * \mathrm{x}_{1}+\mathrm{a}_{12} * \mathrm{x}_{2}=\mathrm{b}_{2} \\
& \cdot \\
& \cdot \\
& \cdot \\
& \mathrm{a}_{\mathrm{m} 1} * \mathrm{x}_{1}+\mathrm{a}_{\mathrm{m} 2} * \mathrm{x}_{2}=\mathrm{b}_{\mathrm{m}}
\end{aligned}
$$$$
\text { or }
$$

We seek solutions for $\mathrm{x}_{1}$ and $\mathrm{x}_{2}$ such that all $\mathrm{b}_{\mathrm{i}}$ are negative or zero for phases of one assemblage and positive or zero for all phases in the other assemblage. The problem is formulated by replacing equalities with appropriate weak inequalities (Table 4). Before attempting solutions, the original problem was modified in two ways. First, we are interested in the first appearance of actinolite, so it is convenient to find solutions for unit amounts of actinolite $\left(b_{a c t}=1\right)$. Second, the MATLAB software requires that problems be written only with equality or "less than or equal to" constraints. Consequently, we set $b_{\text {act }}=1$, multiply all constraints on the coefficients of assemblage 2 by -1 , and reverse the direction of the weak inequalities for assemblage 2 (Table 4 , modified). The solution to the modified problem is also a solution for the original problem, but for unit actinolite.

Linear programming finds solutions at the boundaries of the feasible solution-space by optimizing a linear function of the variables, $\mathrm{Z}=\mathrm{f}\left(\mathrm{x}_{\mathrm{i}}\right)$. One might find a 
solution for $\mathbf{X}$, subject to the constraints, at the maximum or minimum of the objective function, $\mathrm{Z}$. A simple objective criterion might be: maximize $\mathrm{Z}=\mathrm{x}_{1}$, or minimize $\mathrm{Z}=\mathrm{x}_{1}+\mathrm{x}_{2}$. Ordinarily, it is convenient to explore possible solutions simply by minimizing and maximizing each element of $\mathbf{X}$, in turn.

Table 4 and Figure 7 illustrate feasible solutions to the problem. Solutions for the maximum and minimum feasible values of $x_{1}$ and $x_{2}$, subject to the constraints (Table 4), are illustrated as dots in Figure 7. These solutions were calculated for unit actinolite and define a contour of unit positive actinolite in the reaction space. The solutions lie on vectors labeled $\left(\mathrm{Ep}_{1}\right)$ and $\left(\mathrm{Pmp}_{2}\right)$, corresponding to mass-balances in which $\mathrm{Ep}_{1}$ and $\mathrm{Pmp}_{2}$ do not participate (Table 4). These vectors define an unbounded region of feasible solutions (shaded area, Fig. 7) that includes all possible combinations of the basis vectors that produce actinolite, subject to the constraints that coefficients of phases in assemblage 2 are positive and the coefficients of phases in assemblage 1 are negative. The complementary feasible solutionspace that corresponds to the reverse of these mass-balances is shown as the stippled region (Fig. 7). The portion of the contour of unit actinolite that lies between the vectors labeled $\left(\mathrm{Ep}_{1}\right)$ and $\left(\mathrm{Pmp}_{2}\right)$ corresponds to all possible solutions that yield unit positive actinolite.

\section{DISCUSSION}

\section{Rank of individual assemblages}

The composition matrices of all mineral assemblages that we have tested have a rank equal to the number of phases in the assemblage. We tested model matrices of lower rank for each assemblage studied, and found in each case that the trial model of lower rank could be rejected. These results are not surprising, because no mineral assemblage requires more independent components than phases. One can always choose the phase compositions themselves as independent components of the system. Likewise, it is not surprising to find that models of lower rank might be rejected if the number of oxides analyzed is much larger than the number of phases. Consequently, the rank of the composition matrix of a single assemblage of minerals usually indicates only a minimum phase-rule variance, which may have little application to variations that may occur in that assemblage.

\section{Rank of combined assemblages}

The matrix formed by combining all seven minerals in assemblages 7174X (excluding prehnite) and SC18 has a rank of five, only one larger than SC18 by itself. Continuous variations among the minerals in these rocks thus require five independent components. An enlarged matrix that included all of the analyzed minerals in samples B62, SC5, SC18, SC34 and SC52 also has a rank of five. This finding strongly suggests that variations in the four-phase assemblages require five independent components, and that the four-phase assemblages have three degrees of freedom. There are six oxides in the composition matrix and, in view of the complex structural formulas of the minerals, one might anticipate that all six components would be independent. Nevertheless, only five major oxides are required to describe independent variations in the phase assemblages, perhaps reflecting the fact that the content of manganese is minor in all analyzed minerals.

\section{Reactions controlling the first appearance of actinolite}

The reaction space shown in Figure 7 illustrates the semi-infinite number of permissible mass-balances that relate assemblages 1 and 2 . This result confirms that reaction relationships exist between assemblages in Zones A1 and A2. This result could be anticipated, but not demonstrated, from the projections (Figs. 6A, B). Any linear combination of (Ep1) and (Pmp2) is a permissible mass-balance between the two assemblages, and describes a possible net whole-rock reaction between the two rocks. The two assemblages must have formed under different, but possibly not very different, physical conditions. Such continuous reactions cannot be balanced uniquely, reflecting the high variance of the assemblages.

The general form of the continuous reactions that produce actinolite is indicated by the limiting mass-balances. Chlorite participates in the reactions, but its abundance declines very little (Table 4, Fig. 7). In each of the mass-balances, pumpellyite is consumed and epidote is produced with progress on the reactions, as shown by the changes in the phase coefficients (Table 4, Fig. 7). The general form of the continuous reaction that produces actinolite must be approximately Pmp $+\mathrm{Chl}=$ Act + Ep. Ignoring the differences in phase compositions and the need to balance with excess albite, quartz and $\mathrm{H}_{2} \mathrm{O}$, the molar changes in mineral abundance across the limiting mass-balances are, approximately (Table 4),

$$
\text { 2.7 Pmp + 0.3 Chl = 1.0 Act + 4.2 Ep }(\text { Pmp2) }
$$

and

$$
\text { 2.1 Pmp + 0.4 Chl = 1.0 Act + 3.2 Ep }(\mathrm{Ep} 1)
$$

Each of these is similar to model reaction (1) in NCMASH, which can be balanced for unit amphibole:

$$
\begin{aligned}
& \text { 3.6 } \mathrm{Pmp}+0.3 \mathrm{Cln}(+4.1 \mathrm{Qtz}) \\
& =1.0 \mathrm{Tr}+6.1 \mathrm{Czo}\left(+9.6 \mathrm{H}_{2} \mathrm{O}\right)
\end{aligned}
$$

Consequently, the detailed analysis confirms that discontinuous reactions (1) and (9), inferred from the sim- 
plified NCMASH system, approximate the continuous reactions (7) and (8) that are implied by the natural assemblages.

The changes of phase compositions during the net whole-rock reaction (Table 5) were calculated directly from the rank-5 model compositions that are indistinguishable from the analyzed compositions within analytical uncertainty (Table 3 ). The $\mathrm{Al}$ content of chlorite increases only slightly in the higher-grade assemblage, but both epidote and pumpellyite are noticeably more aluminous. The pumpellyite becomes more magnesian, whereas the chlorite becomes less magnesian as the Chl-Pmp tieline (Fig. 6A) rotates with increasing grade. Ferric iron decreases with increasing grade in both epidote and pumpellyite.

\section{Continued production of actinolite}

Actinolite becomes more abundant as metamorphic grade increases in zone A2, and pumpellyite disappears altogether at the greenschist-facies boundary (Fig. 3). Pumpellyite may be sufficiently abundant in mafic rocks to produce the amount of actinolite indicated by reactions (7) and (8). Pumpellyite typically constitutes 5$15 \%$ of mafic rocks in Zone A1, and actinolite may represent as much as $10 \%$ of mafic rocks near the boundary between the prehnite-pumpellyite and greenschist facies. The limiting mass-balances, (Ep1) and $(\mathrm{Pmp} 2)$, require at least two molar units of pumpellyite to produce one unit of actinolite. Because the number of oxygen atoms in the pumpellyite and actinolite formulas are similar, these coefficients also give a rough idea of the modal units of each that are involved. Thus, there appears to be enough pumpellyite available in some rocks to produce the amount of actinolite observed, but we cannot rule out the possibility that progress on other continuous reactions might also produce actinolite.

Thompson et al. (1982) showed that three net-transfer reactions are sufficient to describe all possible continuous reactions in which pumpellyite does not participate. Because the amount of $\mathrm{Na}$ in actinolite is so low in our samples, net progress on two of the independent reactions, which consume albite and create the edenite component in amphibole, must have been essentially nil. Projected from excess quartz and $\mathrm{H}_{2} \mathrm{O}$, the remaining reaction has the form:

TABLE 5. COMPOSITIONS OF PHASES IN RANK-5 MODEL

Chl1 Ep1 Pmp1 Act2 Ch12 Ep2 Pmp2

\begin{tabular}{llllllll}
\hline & & & & & & & \\
$\mathrm{Al} /\left(\mathrm{Al}+\mathrm{Fe}^{3+}+\mathrm{Fe}^{2+}+\mathrm{Mn}+\mathrm{Mg}\right)$ & 0.31 & 0.67 & 0.02 & 0.34 & & 0.73 \\
$\mathrm{Al} /\left(\mathrm{Al}+\mathrm{Fe}^{3+}\right)$ & 1.00 & 0.69 & 0.81 & 1.00 & 1.00 & 0.73 & 0.88 \\
$\mathrm{Mg} /\left(\mathrm{Mg}+\mathrm{Fe}^{2+}+\mathrm{Mn}\right)$ & 0.57 & 0.46 & 0.66 & 0.51 & 0.55 \\
$\mathrm{Fe}^{3+} /\left(\mathrm{Fe}^{3+}+\mathrm{Fe}^{2+}\right)$ & 0.00 & 1.00 & 0.61 & 0.00 & 0.00 & 1.00 & 0.58 \\
& & & & & & & \\
\hline
\end{tabular}

$$
\mathrm{Czo}+0.6 \mathrm{Cln}=\mathrm{Tr}+2.1 \mathrm{tk}
$$

where $t k$ is Tschermak's exchange component, $\mathrm{A}_{2} \mathrm{Mg}_{-1}$ $\mathrm{Si}_{-1}$, which could reside in either the amphibole or the chlorite. Because Tr in reaction (10) is the additive component representing all amphibole, any progress to the right must produce a net increase in total amphibole, regardless of the way in which $t k$ is partitioned between amphibole and chlorite. Some progress of such a reaction may be required in order to explain the abundance of actinolite at higher grades.

The effective bulk compositions defined by many assemblages from zone A2 are more magnesian than the composition of assemblages from zone A1. In fact, many assemblages in zone A2 do not intersect the region defined by Pmp-Chl tielines from zone A1 (Fig. 6 ). This observation is puzzling, because zones A1 and A2 encompass the same stratigraphic range of volcanic rocks, and whole-rock chemical compositions of rocks from the two zones span the same range of $\mathrm{Mg} /(\mathrm{Mg}+$ $\mathrm{Fe}$ ) (Springer \& Day, unpubl. data). We have analyzed the minerals from only seven samples from zone A1, and it is possible that they do not represent the full range of rock compositions. One might also argue that actinolite in magnesian compositions was produced by a pumpellyite-absent reaction, such as reaction (10). This hypothesis would require that chlorite decompose to a magnesian actinolite and a more Al- and Fe-rich chlorite. The shift in the composition of the chlorite indicated by the model (Table 5) is compatible with the conversion of chlorite, by reaction (10), to a mixture of roughly $85 \%$ chlorite $+15 \%$ actinolite by volume. Because reaction (10) does not involve pumpellyite, pumpellyite in zone A2 would have to be explained as a relic from lower grades that has not re-equilibrated or reacted as actinolite crystallized. The demonstrated reaction-relationships [reactions (7) and (8)] and the disappearance of pumpellyite at the greenschist-facies boundary suggest, however, that the metastable persistence of pumpellyite and progress on reaction (10) cannot be the whole explanation for the high-magnesium mineral assemblages.

At least two sources of additional magnesium could contribute to the higher magnesium contents of zoneA2 assemblages. As shown in Figure 5, relict clinopyroxene in these rocks is typically much more magnesian than the metamorphic minerals. Any irreversible reaction by which this clinopyroxene disappears, such as those described by Fagan \& Day (1997), will increase the magnesium content of the metamorphic assemblage. Our observations suggest, however, that large phenocrysts of clinopyroxene are virtually unaltered in most rocks from zones A1 and A2. Either significant progress on the clinopyroxene-consuming reactions does not occur until the greenschist facies, or progress on such irreversible reactions is limited to finegrained clinopyroxene in the altered groundmass. 
An alternative source of additional magnesium may be the weakly altered, originally glassy groundmass itself, which persists in both zones A1 and A2 (Fig. 4). Average basalt (B, Fig. 5) is more magnesian than mixtures of pumpellyite and chlorite defined by typical Pmp-Chl tielines in zone A1 (Fig. 6). If pumpellyite and chlorite appear first in Fe-rich regions of the groundmass, recrystallization of the progressively more magnesian groundmass, coupled with progress on reactions (7) and (8), might explain the fact that most zone-A2 and zone-A1 assemblages do not overlap significantly in projection (Fig. 6A).

There is considerable variation in the position of three-phase Act $+\mathrm{Chl}+$ Pmp fields in Figure 6A. If the metamorphic assemblage is divariant, equilibrium compositions of minerals cannot be a function of effective bulk composition at constant $\mathrm{P}, \mathrm{T}$, and some of this variation might reflect failure to achieve equilibrium. However, if the variance of the mineral assemblage is higher, equilibrium compositions of coexisting minerals are permitted to vary with effective bulk composition, even at constant $\mathrm{P}$ and $\mathrm{T}$. Our calculations suggest that the assemblages $(\mathrm{Act}+\mathrm{Chl}+\mathrm{Ep}+\mathrm{Pmp})$ require five independent components and must have three degrees of freedom. Consequently, even if equilibrium were achieved, one might expect that the compositions of coexisting minerals would vary with effective bulk composition. Therefore, the apparent overlap of threephase triangles in Figure 6 is at least partly an artifact of the projections, which are inadequate to display all five independent variations in the compositions of the minerals.

Our attempts to understand the first appearance of actinolite in the assemblage pumpellyite + epidote + chlorite have implications for two issues. We modeled four-phase mineral assemblages in a system of six oxide components, after projection from albite, quartz and $\mathrm{H}_{2} \mathrm{O}$, implying that the phase-rule variance might be four. The algebraic analysis suggests that five independent components are sufficient to describe the variations and that models with only four independent components are inadequate. The four-phase assemblages must have three phase-rule degrees of freedom, a fact that was not anticipated before the algebraic analysis. High-variance continuous reactions among the assemblages cannot be balanced uniquely, and even their form may change with bulk composition. In the case analyzed here, the possible mass-balances are limited by reactions having the same general form. Whether or not there are limits to the non-uniqueness of continuous reactions that represent useful constraints on the compositional systematics of such assemblages, in general, remains a consideration for further work.

The second issue is the role of irreversible processes in understanding compositional variation of minerals in very-low-grade metamorphic rocks. Because relict minerals and textures are common, and barely recrystallized ultra-fine-grained matrix is abundant in most low-grade volcanic rocks, there is a strong basis for assuming that non-equilibrium processes have a major influence on the progress of metamorphic reactions. On the basis of this study, further work is needed in order to test whether the participation of the altered groundmass in the actinolite-forming process is required to explain the differences observed in assemblages in zones A1 and A2.

\section{Conclusions}

The first appearance of actinolite in metavolcanic rocks of the western Sierra Nevada is controlled by a continuous reaction with the general form: Pmp $+\mathrm{Chl}=$ Act + Ep, balanced as appropriate by ubiquitous albite, quartz and $\mathrm{H}_{2} \mathrm{O}$. During the course of this reaction, the analyzed compositions of the chlorite, epidote and pumpellyite become more aluminous, pumpellyite becomes more magnesian, and the chlorite becomes more iron-rich. Ferric iron decreases in both epidote and pumpellyite. Our calculations suggest that this reaction is trivariant and that mineral compositions are not uniquely determined, even at constant $\mathrm{P}$ and $\mathrm{T}$. Consequently, apparent reaction relationships in simplified mineral projections cannot be interpreted definitively.

The effective bulk compositions of actinolite-bearing assemblages in zone A2 are commonly more magnesian than the actinolite-free assemblages in zone A1. This observation is best explained by irreversible consumption of relatively magnesian altered groundmass or fine-grained clinopyroxene.

\section{ACKNOWLEDGEMENTS}

It is a pleasure to have this opportunity to celebrate the career of Dugald Carmichael. His wide-ranging career included seminal work on the petrology of mafic rocks metamorphosed at low-grade, and the significance of equilibria in prehnite- and pumpellyite-bearing assemblages. His grasp of the "big picture" and his elegant explanations of the basic underpinnings of our science have been an inspiration, not only for us, but for future generations of metamorphic petrologists.

Comments and reviews by N. Bégin, E. Essene, C.V. Guidotti, and R.F. Martin are gratefully acknowledged. This work was supported in part by NSF grant EAR9419115 (Day) and BURC grant 2659 (Springer).

\section{REFERENCES}

BEARD, J.S. \& DAY, H.W. (1987): The Smartville intrusive complex, Sierra Nevada, California: the core of a rifted arc. Geol. Soc. Am., Bull. 99, 779-791.

BEIERSDORFER, R.E. (1992): Metamorphism of the Smartville Complex and Contiguous Rocks, Northern Sierra Nevada and Klamath Mountains, California. Ph.D. thesis, Univ. of California Davis, Davis, California. 
\& DAY, H.W. (1995): Paragenesis of pumpellyite in low-grade mafic rocks. In Low-Grade Metamorphism of Mafic Rocks (P. Schiffman \& H.W. Day, eds.). Geol. Soc. Am., Spec. Pap. 296, 5-28.

Bevins, R.E. \& Robinson, D. (1993): Parageneses of Ordovician sub-greenschist to greenschist facies metabasites from Wales, U.K. Eur. J. Mineral. 5, 925-935.

BRÖCKER, M. \& DAY, H.W. (1995): Low-grade blueschist metamorphism of metagraywackes, eastern Franciscan complex, northern California. J. Metamorph. Geol. 13, 61-78.

Brown, E.H. (1977): Phase equilibria among pumpellyite, lawsonite, epidote, and associated minerals in low-grade metamorphic rocks. Contrib. Mineral. Petrol. 64, 123-136.

Coombs, D.S., Nakamura, Y. \& Vuagnat, M. (1976): Pumpellyite-actinolite facies schists of the Taveyanne Formation near Loeche, Valais, Switzerland. J. Petrol. 17, 440-471.

DAY, H.W. (1972): Geometrical analysis of phase equilibria in ternary systems of six phases. Am. J. Sci. 272, 711-734.

(1992): Tectonic setting and metamorphism of the Sierra Nevada, California. In Field Guide to the Geology and Metamorphism of the Franciscan Complex and Western Metamorphic Belt of Northern California (P. Schiffman \& D. Wagner, eds.). California Division of Mines and Geology, Spec. Publ. 114, 12-28.

Blake, M.C., Ernst, W.G., Hacker, B.R., Howard, K., JACOBSEN, C., SPRINGER, R.K., TODD, V. \& WENTWORTH, C. (2003): A preliminary metamorphic map of California. Geol. Soc. Am., Abstr. Programs 34, 96.

FAGAN, T.J. \& DAY, H.W. (1997): Formation of amphibole after clinopyroxene by dehydration reactions: implications for pseudomorphic replacement and mass fluxes. Geology 25, 395-398.

FisHER, G.W. (1989): Matrix analysis of metamorphic mineral assemblages and reactions. Contrib. Mineral. Petrol. 102, 69-77.

(1990): The exploration of reaction space. In FluidMineral Interactions: a Tribute to H.P. Eugster (R.J. Spencer \& I-Ming Chou, eds.). Geochem. Soc., Spec. Publ. 2, 133-139.

Frey, M., De Capitani, C. \& Liou, J.G. (1991): A new petrogenetic grid for low-grade metabasites. J. Metamorph. Geol. 9, 497-509.

Giaramita, M.J. \& DAY, H.W. (1990): Error propagation in calculations of structural formulas. Am. Mineral. 75, 170182.

GreENWOOD, H.J. (1967): The N-dimensional tieline problem. Geochim. Cosmochim. Acta 31, 465-490.

Hadley, G. (1962): Linear Programming. Addison-Wesley Publishing Co., Reading, Massachusetts.
Harte, B. \& Graham, C.M. (1975): The graphical analysis of greenschist to amphibolite facies mineral assemblages in metabasites. J. Petrol. 16, 347-370.

HillieR, F.S.\& Lieberman, G.J. (1974): Operations Research. Holden-Day, Inc., San Francisco, California.

IRWIN, W.P. \& WoODEN, J.L. (2001): Maps showing plutons and accreted terranes of the Sierra Nevada, California, with a tabulation of U/Pb isotopic ages. U.S. Geol. Surv., OpenFile Rep. 01-299.

LAIRD, J. (1980): Phase equilibria in mafic schist from Vermont. J. Petrol. 21, 1-37.

Le Maitre, R.W. (1976): The chemical variability of some common igneous rocks. J. Petrol. 17, 589-637.

Liou, J.G., Maruyama, S.\& Cho, Moonsue. (1985): Phase equilibria and mineral parageneses of metabasites in lowgrade metamorphism. Mineral. Mag. 49, 321-334.

\& (1987): Very low-grade metamorphism of volcanic and volcaniclastic rocks - mineral assemblages and mineral facies. In Low Temperature Metamorphism (M. Frey, ed.). Blackie \& Son, Glasgow, U.K. (59-113).

PATRICK, B.E. \& DAY, H.W. (1989): Controls on the first appearance of jadeitic pyroxene, northern Diablo Range, California. J. Metamorph. Geol. 7, 629-639.

Powell, W.G., Carmichael, D.M. \& Hodgson, C.J. (1993): Thermobarometry in a subgreenschist to greenschist transition in metabasites of the Abitibi greenstone belt, Superior Province, Canada. J. Metamorph. Geol. 11, 165-178.

Schiffman, P. \& DAY, H.W. (1999): Petrological methods for the study of very low grade metabasites. In Very Low Grade Metamorphism (second edition; M. Frey \& D. Robinson, eds.). Blackwell Scientific, Oxford, U.K. (108142).

Schweickert, R.A., HANSON, R.E. \& GiRTy, G.H. (1999): Accretionary tectonics of the western Sierra Nevada metamorphic belt. In Geologic Field Trips in Northern California (D.L. Wagner \& S.A. Graham, eds.). California Division of Mines and Geology, Spec. Publ. 119, 33-79.

SPRINGER, R.K. \& DAY, H.W. (2002): Hydrothermal amphibole in subgreenschist facies mafic rocks, western Sierra Nevada, California. Schweiz. Mineral. Petrogr. Mitt. 82, 341354.

\& BEIERSDORFER, R.E. (1992): Prehnitepumpellyite to greenschist facies transition, Smartville Complex, near Auburn, California. J. Metamorph. Geol. 10, 147-170.

Tobisch, O.T., Paterson, S.R., SAleeby, J.B. \& Geary, E.E. (1989): Nature and timing of deformation in the Foothills terrane, central Sierra Nevada, California: its bearing on orogenesis. Geol. Soc. Am., Bull. 101, 401-413. 
THOMPSON, J.B., JR. (1982): Reaction space: an algebraic and geometric approach. In Characterization of Metamorphism through Mineral Equilibria (J.M. Ferry, ed.). Rev. Mineral. 10, 33-52.

LAIRD, J. \& ThOMPson, A.B. (1982): Reactions in amphibolite, greenschist and blueschist. J. Petrol. 23, 1-27.
Xenophontos, C. (1984): Geology, Petrology, and Geochemistry of Part of the Smartville Complex, Northern Sierra Nevada, California. Ph.D. thesis, Univ. of California Davis, Davis, California.

Received November 3, 2003, revised manuscript accepted April 25,2004

\section{APPENDIX}

This appendix includes two tables. Table A1 lists the detailed locations of samples mentioned or illustrated in the text. Table A2 gives the compositions of minerals in samples 7174X and SC18. All analyses were made on a Cameca SX-50 automated electron microprobe housed in the Department of Geology at University of California, Davis. The instrument was typically operated with an accelerating potential of $15 \mathrm{kV}$, a beam current of $10 \mathrm{nA}$, and a tightly focused beam approximately one $\mu \mathrm{m}$ in diameter. Silicate and oxide standards were used, and all data were reduced using a ZAF correction. Results of analyses are presented as the mean and standard deviation of several spots in a thin section. Structural formulas may be calculated either directly from the mean of the analytical results or by taking the mean of the formulas calculated for the several individual spot-analyses. For most purposes, the differences between the structural formula of the mean composition and the mean structural formula are not significant (Giaramita \& Day 1990). In this study, the structural formulas were calculated directly from the mean compositions, but the associated one-sigma uncertainties are the standard deviations of the structural formulas calculated from several analytical datasets. This procedure is convenient because it avoids having to propagate analytical uncertainties by the more rigorous, but cumbersome, analytical methods. In most cases, the differences between the two methods are not significant for studies such as this (Giaramita \& Day 1990).

TABI.E A1. SAMPLE LOCATIONS

\begin{tabular}{llll}
\hline Sample & $\begin{array}{l}\text { 7.5 Minute } \\
\text { Quadrangle }\end{array}$ & UTM-N & Coordinates \\
& & & \\
& UTM-E \\
SC100X & Carbondale & 4261900 & 666600 \\
7172 & Folsom SE & 4269410 & 663660 \\
$7174 \mathrm{X}$ & Folsom SE & 4265250 & 666040 \\
$79-142$ & Smartville & 4342315 & 644026 \\
SC5 & Clatksville & 4277050 & 668310 \\
SC18 & Latrobe & 4265560 & 678300 \\
SC34 & Folsom SE & 4274510 & 670080 \\
SC52 & Folsom SE & 4266460 & 670580 \\
B62 & Folsom SE & 4274520 & 669290 \\
& & & \\
\hline
\end{tabular}


TABLE A2. CHEMICAI COMPOSITION OF MINERALS FROM ZONES A1 AND A2

\begin{tabular}{|c|c|c|c|c|c|c|c|c|c|c|c|c|c|c|}
\hline \multirow{2}{*}{$\begin{array}{l}\text { Mineral } \\
\text { Sample } \\
\text { Zone } \\
\text { Analyses }\end{array}$} & \multicolumn{2}{|c|}{$\begin{array}{c}\text { Act } \\
\text { SC18 }\end{array}$} & $\begin{array}{r}\mathrm{Cl} \\
717 \\
\mathrm{~A}\end{array}$ & $\begin{array}{l}1 \\
4 X \\
1\end{array}$ & $\begin{array}{r}\mathrm{C} \\
\mathrm{SC} \\
\mathrm{A}\end{array}$ & & $\begin{array}{r}\mathrm{E} \\
717 \\
\mathrm{~A}\end{array}$ & $\begin{array}{l}p \\
4 X \\
1\end{array}$ & $\begin{array}{r}\mathrm{E} \\
\mathrm{SO} \\
\mathrm{A}\end{array}$ & & & $\begin{array}{l}p \\
4 X \\
1\end{array}$ & & $\begin{array}{l}\text { p } \\
18 \\
2\end{array}$ \\
\hline & 2 & $\sigma$ & 8 & $\sigma$ & 15 & $\sigma$ & 2 & $\sigma$ & 4 & $\sigma$ & 7 & $\sigma$ & 2 & $\sigma$ \\
\hline $\mathrm{SiO}_{2}$ wt. $\%$ & 55.28 & 0.02 & 28.37 & 0.37 & 26.26 & 0.27 & 36.36 & 0.27 & 35.89 & 0.37 & 37.14 & 0.45 & 36.52 & 0.09 \\
\hline $\mathrm{Al}_{2} \mathrm{O}_{3}$ & b.d. & & 17.81 & 0.58 & 19.25 & 0.22 & 22.90 & 0.33 & 24.61 & 0.53 & 21.32 & 0.68 & 23.40 & 0.04 \\
\hline $\mathrm{Fe}_{2} \mathrm{O}_{3}$ & 0.60 & 0.04 & & & n.a & & 16.29 & 0.36 & 13.98 & 0.65 & n.a & & n.a & \\
\hline $\mathrm{FeO}$ & 13.57 & 0.45 & 23.98 & 0.77 & 25.72 & 0.32 & n.a. & & n.a & & 11.16 & 1.02 & 7.79 & 0.35 \\
\hline $\mathrm{MnO}$ & 0.32 & 0.02 & 0.46 & 0.03 & 0.46 & 0.03 & 0.19 & 0.12 & 0.24 & 0.05 & 0.11 & 0.04 & 0.27 & 0.09 \\
\hline $\mathrm{MgO}$ & 15.06 & 0.35 & 17.98 & 0.71 & 15.50 & 0.23 & b.d. & & b.d. & & 2.12 & 0.15 & 2.40 & 0.13 \\
\hline $\mathrm{CaO}$ & 12.66 & 0.06 & 0.13 & 0.04 & 0.16 & 0.11 & 22.26 & 0.26 & 22.84 & 0.16 & 22.47 & 0.31 & 22.24 & 0.10 \\
\hline $\mathrm{Na}_{2} \mathrm{O}$ & 0.07 & 0.03 & b.d. & & b.d. & & n.a. & & n.a. & & n.a. & & n.a. & \\
\hline $\mathrm{K}_{2} \mathrm{O}$ & b.d. & & b.d. & & b.d. & & n.a. & & n.a. & & n.a. & & n.a. & \\
\hline Subtotal & 97.54 & & 88.73 & & 87.33 & & 97.98 & & 97.55 & & 94.32 & & 92.61 & \\
\hline $\mathrm{H}_{2} \mathrm{O}$ calc. & 2.08 & & 11.62 & & 11.30 & & 1.87 & & 1.87 & & 6.37 & & 6.36 & \\
\hline Total & 99.61 & & 100.35 & & 98.63 & & 99.85 & & 99.42 & & 100.69 & & 98.97 & \\
\hline $\begin{array}{l}\Sigma 0 \\
\Sigma \text { cations }\end{array}$ & 23 & & 14 & & 14 & & 12.5 & & 12.5 & & $\begin{array}{l}24.5 \\
16\end{array}$ & & $\begin{array}{l}24.5 \\
16\end{array}$ & \\
\hline Si apfu & 7.98 & 0.00 & 2.93 & 0.05 & 2.79 & 0.02 & 2.92 & 0.00 & 2.88 & 0.01 & 6.01 & 0.05 & 5.95 & 0.01 \\
\hline $\mathrm{Al}$ & 0.10 & 0.01 & 2.17 & 0.03 & 2.41 & 0.02 & 2.17 & 0.01 & 2.33 & 0.05 & 4.06 & 0.15 & 4.49 & 0.01 \\
\hline $\mathrm{Fe}^{3}$ & & & & & & & 0.98 & 0.01 & 0.84 & 0.04 & 0.92 & 0.12 & 0.62 & 0.04 \\
\hline $\mathrm{Fe}^{2+}$ & 1.64 & 0.05 & 2.07 & 0.03 & 2.29 & 0.04 & & & & & 0.59 & 0.05 & 0.45 & 0.01 \\
\hline $\mathrm{Mn}$ & 0.04 & 0.00 & 0.04 & 0.00 & 0.04 & 0.00 & 0.01 & 0.01 & 0.02 & 0.00 & 0.01 & 0.01 & 0.04 & 0.01 \\
\hline $\mathrm{Mg}$ & 3.24 & 0.08 & 2.77 & 0.05 & 2.46 & 0.02 & & & & & 0.51 & 0.04 & 0.58 & 0.03 \\
\hline $\mathrm{Ca}$ & 1.96 & 0.01 & 0.01 & 0.00 & 0.02 & 0.01 & 1.92 & 0.04 & 1.96 & 0.02 & 3.89 & 0.04 & 3.88 & 0.02 \\
\hline $\mathrm{Na}$ & 0.02 & 0.01 & & & & & & & & & & & & \\
\hline CAT SUM & 14.98 & 0.00 & 9.99 & 0.04 & 10.00 & 0.01 & 8.00 & 0.01 & 8.03 & 0.01 & 16.00 & & 16.00 & \\
\hline $\begin{array}{l}\mathrm{Mg} / \\
\left(\mathrm{Mg}+\mathrm{Fe}^{2+}\right)\end{array}$ & 0.66 & 0.01 & 0.57 & 0.00 & 0.52 & 0.01 & & & & & 0.47 & 0.04 & 0.57 & 0.12 \\
\hline $\mathrm{AF}^{\prime}$ & -0.41 & 0.01 & 0.18 & 0.00 & 0.20 & 0.00 & & & & & -0.63 & 0.18 & -0.53 & 0.13 \\
\hline $\mathrm{Fe}^{3+} /$ & & & & & & & & & & & & & & \\
\hline$\left(\mathrm{Fe}^{31}+\mathrm{Ca}\right)$ & 0.00 & & & & & & 0.20 & 0.00 & 0.18 & 0.01 & 0.11 & & 0.07 & \\
\hline$\Lambda^{\prime}$ & -0.91 & 0.02 & & & & & 0.31 & 0.00 & 0.33 & 0.01 & 0.29 & & 0.33 & \\
\hline
\end{tabular}

$\mathrm{A}^{\prime}$ : transformed coordinate in chlorite projection; $\mathrm{AF}^{\prime}$ : transformed coordinate in epidote projection; b.d.: below detection limi1; $\mathrm{n}$.a.: not analyzed. $\mathrm{TiO}_{2}$ and $\mathrm{F}$ : below detection in all samples; $\sigma$ for small number of analyses probably underestimates true value. The structural formulas are expressed in atoms per formula unit (apfu). 